Hispania, LVIL/2, núm. 196 (1997)

\title{
ENTRE LOS AUSTRIAS Y LOS BORBONES. LA REALIDAD DE UN TRIBUNAL INQUISITORIAL DE DISTRITO: LOGROÑO, 1690-1705
}

\author{
por
}

\section{MARINA TORRES ARCE}

Universidad de Cantabria

RESUMEN: Cambio de dinastía, conflicto sucesorio, inestabilidad social y proyectos de reforma en todos los ámbitos, podran definir, a grandes rasgos, los últimos años del siglo XVII y principios del XVIII en España. La Inquisición lógicamente se vio afectada por estas coyunturas. En torno al fin del siglo XVII, los fundamentos en los que descansaba la estructura inquisitorial eran fuertemente cuestionados por diferentes sectores del cuerpo de la Monarquia y las bases económicas y sociales del Santo Oficio dejaban la centuria sumidas en una profunda crisis.

Con la llegada de Felipe $V$, en colaboración con el Consejo de la Suprema, se promovieron numerosas iniciativas de reforma con las que se buscó la ade cuación de las estructuras y funcionamiento de la Inquisición a las nuevas circunstancias en las que les tocaba actuar.

El objetivo de este trabajo ha sido conocer de que manera afectó esta coyuntura a la Inquisición, a través del estudio de su repercusión en la estructura burocrática de un tribunal inquisitorial de distrito como el de Logroño. Por tanto, la caracterización sociológica del grupo burocrático al servicio del tribunal, inquisidores y oficiales, será el eje a través del cual intentaremos acercamos a la realidad de este tribunal en los años de paso del siglo XVI al XVII.

Palabras clave. España, Inquistción, historia social y política, siglos xvixvir.

ABSTRACT: The last years of the 17th century and the early 18th in Spain could be defined as a change in dinasty, conflict of succession, social instability and projects of reformation in all fields. Logically, the Inquisition was also affected by these factors. Towards the end of the 17th century, the foundations on which the inquisitorial structure lay were zealousy questioned by different sectors of the body of the Monarchy, and the economic and social basis of the Holy Office left the century inmersed in a deep crisis.

Hixpatia, LVIL/2, nu்m. 196 (1997) 731-773 
With the arrival of Philip $V$ in collaboration with the Supreme Council, a great number of reform initiatives were fostered in order to attain the adaptation of the structures and functioning of the Inquisition to the new set of circumstances in which they had to act.

The aim of this work has been to unearth in what way this juncture affected the daily dynamics of a district inquisitorial tribunal, like the one in Logrono, that is to say, what impact this situation had on its structure. Therefore, the sociologic characterisation of the bureaucratic group in service to the tribunal, inquisitors and officials, would be the fundamental idea with which we shall try to grasp the reality of this tribunal in the passing years between the 17 th and 18 th centuries.

KEY WORDS: Spain, 17th and 18th centuries, Inquisition, Social History.

En la historiografía inquisitorial, el siglo xvII ha sido, hasta hace bien poco, el período peor conocido de cuantos componen los casi trescientos años de historia de esta institución tan característica de la Monarquía Católica.

En un intento de irnos acercando con mayor atención y profundidad a lo que fue del Santo Oficio en el, aún oscuro, Siglo de las Luces, hemos planteado el trabajo que sigue, centrándonos en un breve período de tiempo, los años 1690 a 1705 o lo que es lo mismo, la transición del siglo XvII al xvirr.

En estos quince años, la inestabilidad arrastrada del reinado del último Austria, el cambio dinástico y el inicio de la contienda sucesoria española en Europa, junto a los iniciales proyectos gubernamentales de reforma en la administración central y demás organismos de la Corona, provocaron tensiones y conflictos en ciertos sectores de la sociedad, entre los que estuvo el inquisitorial.

Para la Inquisición, esta etapa ha sido tradicionalmente considerada como el momento en el que la progresiva pérdida de aliento que venía padeciendo desde mediados del xvIr, redujo a la institución a una existencia diletante, inmersa en una profunda crisis económica y con sus bases sociales intensamente socavadas.

Ciertamente, en torno al fin del siglo xviI, los fundamentos en los que descansaba la estructura inquisitorial fueron cuestionados por diferentes sectores del cuerpo de la Monarquía, perdiendo así la Inquisición el apoyo de parte de ellos. Además, la penuria económica que padecía el fisco inquisitorial se agudizaba cada vez más y todo ello, junto a las circunstancias especialmente delicadas que vivía el reino en esos momentos, afectó tanto al funcionamiento, como a la composición orgánica del Santo Oficio.

Desidia, anquilosamiento y burocratización en la actividad desarrollada por un personal inquisitorial, cada vez menos identificado con los objetivos de la institución a la que servía, sería el panorama que, en principio, parece que podamos encontrar en cualquier tribunal inquisitorial en esta etapa.

Estas circunstancias serían las que llevaron a que, desde la dirección inquisitorial y la propia Corona, se promoviesen numerosas iniciativas de reforma interna en el Santo Oficio, tocantes, en especial, a la cuestión del 
saneamiento de su hacienda y de la dotación y correcto funcionamiento del personal a su servicio.

El objetivo del presente trabajo ha sido establecer cuál fue la realidad en la que estuvo inmersa la Inquisición en este breve período, o lo que es lo mismo, observar de qué manera repercutieron estos acontecimientos en su dinámica cotidiana, a través del estudio del funcionamiento orgánico de uno de sus tribunales de distrito, el de Logroño.

La brevedad del período estudiado no nos permitirá, obviamente, determinar si el comportamiento de la Inquisición, desde el observatorio elegido, se ajustó a la situación mencionada líneas atrás. Nuestra intención no es más que situar a la institución, en los inicios de su última etapa, para desde aquí, afrontar en estudios posteriores, su realidad durante la centuria del XVIII.

El eje principal sobre el que se ha estructurado nuestra investigación ha sido el análisis de burocracia que servía y configuraba a este tribunal. Es decir, hemos buscado caracterizar a los servidores del tribunal, inquisidores y oficiales, de modo que partiendo de los presupuestos teóricos que definían sus figuras y observando de qué modo se concretaron en el marco del tribunal de Logroño, podamos ofrecer una pieza más con la que ir conociendo mejor cual fue el modelo organizativo del Santo Oficio en estos momentos.

Al ser tan corto el período estudiado, hemos podido acercarnos de manera muy minuciosa a cada uno de los miembros del tribunal. En la medida en que los datos ofrecidos por la bibliografía especializada y la documentación manejada, fundamentalmente la correspondencia intercambiada entre el tribunal de Logroño y la dirección inquisitorial en las fechas estudiadas, nos lo han permitido, hemos llegado a conocer quienes fueron los inquisidores y oficiales que servian en Logroño por aquellas fechas, cuál era su extracción geográfica, cuáles los grupos socio-económicos de los que se nutrió y entre los que se desenvolvió este tribunal de distrito, cuáles los vínculos y contactos de los miembros del tribunal y sus familias...en definitiva, hemos intentado dar respuestas a algunas cuestiones que nos puedan permitir avistar el modo en que se dotaban y funcionaban las piezas clave de la organización inquisitorial, sus tribunales de distrito, en un momento en el que parecía que todo iba a cambiar en el seno de la Corona hispana.

\section{EL PERSONAL DEL TRIBUNAL dE LOGROÑo: INQUISIDORES Y OFICIALES, 1690-1705}

\section{Los jueces inquisitoriales: la concreción del modelo de inquisidor en Logroño, 1690-1705}

La figura principal de la estructura de personal de la Inquisición eran los inquisidores, pues sólo ellos presidían sus tribunales, valiéndose de la jurisdicción que les era delegada por el Inquisidor General en los títulos de su nombramiento. 
EI inquisidor era pues, el máximo representante de toda la autoridad, poder y prestigio del Santo Oficio sobre el territorio adscrito al tribunal que presidía. Este hecho, junto a la independencia jurídica de que disfrutaba como miembro de esta institución, le llevaron a detentar una posición relevante y codiciada en la sociedad sobre la que ejercía su jurisdicción.

La función principal y definitoria de este cargo era la de ser juez en las causas de fe, pero además, de él dependía todo el gobierno del tribunal, recayendo sobre sus hombros la responsabilidad concerniente a la gestión, administración y dirección de todos los asuntos ${ }^{1}$.

El inquisidor era únicamente responsable ante la dirección inquisitorial, Consejo e Inquisidor General, sin embargo no ejercía su jurisdicción solo, sino colegiadamente con los demás inquisidores que en ese momento sirvieran una plaza en su mismo tribunal.

Entre los inquisidores no había jerarquización, de modo que todos tenían la misma dignificación social, aunque en la práctica, si que se hacía una cierta diferenciación que confería mayor o menor prestigio de autoridad, según la mayor o menor antigüedad que se tuviera en la ocupación del cargo. Así, el inquisidor más antiguo sería el llamado "primer inquisidor».

El número de inquisidores que actuaban en un tribunal no fue nunca fijo, aunque si estuviera fijado.

En 1629 y 1638, Felipe IV y el Inquisidor General Zapata, aprobaron dos Autos de Buen Gobierno, en los cuales se regulaba cual sería el número de inquisidores y oficiales necesarios para el correcto funcionamiento de cada tribunal inquisitorial. Para el de Logroño se estipularon entonces, dos inquisidores y un fiscal ${ }^{2}$. Posteriormente, en diferentes disposiciones dadas por la Corona y dirección inquisitorial, se mantuvo este número como el ideal para nuestro tribunal ${ }^{3}$.

En Logroño, fueron un total de nueve los inquisidores que sirvieron entre 1690 y 1705.

La mayor parte del tiempo fueron dos inquisidores más un fiscal o bien, tres inquisidores, reteniendo el menos antiguo el cargo de fiscal, con lo que, en general, en Logroño la norrna se cumplía, al menos en la etapa estudiada.

1 LEA, H. Ch. Historia de la Inquisición Española, t. II, Madrid: Fundación Universitaria Española, 1985, pág. 92-99; LóPEZ VELA, R. «Estructuras administrativas del Santo Oficio», en Historia de la Inquisición en España y América, t. II, Madrìd: B.A.C., Centro de estudios inquisitoriales, 1993, pág. 169-170 ; Contreras, J. El Santo Oficio de la Inquisición de Galicia (poder, sociedad y cultura) 1560-1700, Madrid; Akal, 1982, págs. 183-185 y 243, 308; MARTínez Milíán, J. La hacienda de la Inquisición, Madrid: Taurus, 1975, págs. 220-221.

2 LÓPEZ VELA, R. «Estructura y funcionamiento de la burocracia inquisitorial (1643-/667)», ел Inquisición española. Nuevas aproximaciones. Madrid: Centro de Estudios inquisitoriales, 1987, págs. 166-168.

3 En 1643 Felipe IV remitió un decreto real al Inquisidor General, Arce Reinoso, indicando, entre otras medidas, que se ajustase el número de inquisidores, fiscales y secretarios de los tribunales a los dos Autos de Buen Gobierno mencionados. Y de nuevo, en 1677 , el Inquisidor General, Sarmiento de Valladadares y Carlos Il reiteraron tal medida. Ibidem.

Hispania, LVIL/2, núm. 196 (1997) 731-773 
Sin embargo, hubo breves espacios de tiempo, en los que ésta tónica se rompió. Entre 1698 y 1700 llegaron a ser cuatro los inquisidores que servían a la vez, tres más el inquisidor-fiscal y entre 1702 y 1705 hubo tres jueces más un fiscal. Aun así, este comportamiento no desdice nuestra afirmación anterior, pues estas discordancias se dieron fundamentalmente, en el intervalo de tiempo en el que coincidían inquisidores que iban a ser trasladados fuera de Logroño e inquisidores que entraban a servir en él, de modo que en el tribunal, si bien no se cumplían estrictamente las disposiciones, sí que se tendía a ello.

Los nueve inquisidores que sirvieron en Logroño durante los quince años que nos ocupan fueron:

- ldo.d.Pedro Nogales Dávila, quien sirvió como inquisidor en Logroño entre 1686 y $1696^{4}$.

- dr.d.Gregorio Ramos Escajadillo y Posadas, que ocupó el cargo de inquisidor entre 1683 y $1698^{\mathrm{s}}$.

- Ido.d.Juan de Argaiz, que aparece como inquisidor entre 1697 y 1699.

- ldo.d.Ignacio Manuel de Aguiar, quien sirvió un año en Logroño, hasta su muerte en $1699^{\circ}$.

- Ido.d.Francisco de Cossio y Otero, que fue inquisidor desde 1696 a 1700 .

- Ido.d.Santiago Hidalgo, que ocupó el cargo de inquisidor en Logroño entre 1698 y $1700^{7}$.

- Ido.d.Juan Antonio de Santelizes, que fue inquisidor desde 1700 hasta $1710^{8}$

- Ido.d.José de Ozcariz y Arneda, quien sirvió entre 1700 y 17059 .

- Y por último, el ldo.d.Jerónimo Ibáñez Zárate, quien ocupó su plaza en Logrono entre 1702 y 1717 , cuando murio ${ }^{10}$.

La mayor parte de estos hombres llegaron al tribunal a ocupar la plaza de promotor fiscal, para en un período de tiempo, en general, breve, pasar a ser inquisidores, manteniendo en algunos casos, también la fiscalía.

Así, Gregorio Ramos Escajadillo fue fiscal en Logroño, entre 1682 y 1685 ". Francisco Cossio lo fue entre abril y diciembre de 1696 y cuando logró la plaza

\footnotetext{
4 CRISTÓBAL, A. Confianza, fidelidad y obediencia. Servidores inquisitoriales y dependencias personales en la ciudad de Logroño (siglo xvil). Logroño: Instituto de Estudios Riojanos, C.S.I.C., 1994, págs. 116-117.

5 Prado Moura, A. de, Inquisición e inquisidores en Castilla. El mibunal de Valladolid durante la crisis del Antiguo Régimen. Valladolid, 1995, pág. 254.

6 A.H.N. Inq. leg. 2220, exp. 307, T/C 8/8/1699.

7 A.H.N. inq. leg. 2220, exp. 272, Logroño, 14/6/1698.

8 A.H.N. Inq. lib. 825, fol. 452 r; leg. 2221, T/I.G. $8 / 6 / 1700$.

A.H.N. Inq. leg. 2220, exp.165; leg. 2221, T/L.G. 8/6/1700; leg. 2222, exp. 2, T/I.G. 29/9/1705.

10 A.H.N. Inq. leg. 2221, exp. 107, Madrid 3/4/1702; leg. 2223, exp. 7.

" Prado Moura, A. de, Inquisición e... opus cil, pág. 68.
} 
de inquisidor, siguió sirviendo la fiscalía ${ }^{12}$. José de Ozcariz también fue fiscal cinco meses, hasta que en diciembre del 1700 obtuvo el nombramiento de inquisidor ${ }^{13}$, lo mismo que Juan Antonio de Santelizes, que en menos de un año pasó a ser inquisidor de Logroño desde su fiscalía ${ }^{14}$. Santiago Hidalgo, por su lado, fue fiscal en Logroño entre 1692 y 93, pasó luego al tribunal de Valladolid con el mismo cargo y años más tarde volvió de nuevo a Logroño, por motivos que trataremos después, esta vez ya como inquisidor ${ }^{15}$.

Solo en un caso, el de Bernardo de la Mata, la ocupación de la fiscalía duró un período de tiempo muy prolongado, pues no fue inquisidor, hasta después de haber sido fiscal durante diez años, desde 1700 hasta $1710^{16}$. Sin embargo, el suyo fue un caso completamente atípico en este tribunal.

Quienes no fueron fiscales en Logroño, antes de ser sus inquisidores, habían ocupado tal plaza en otros tribunales. El ldo.Ibáñez había sido fiscal un año en el tribunal de Mallorca donde sirvió luego como inquisidor ${ }^{17}$, lo mismo que el ldo.Nogales Dávila, quien fue fiscal e inquisidor en el tribunal de Barcelona ${ }^{18}$, antes de ir a Logroño.

En principio, lo más común era que el paso del cargo de fiscal a inquisidor se produjese en un mismo tribunal, pero hubo quienes pasaron de un tribunal a otro en el momento de ascender de un puesto a otro. Ya se ha señalado el caso del ldo. Hidalgo y algo similar le debió de ocurrir al ldo.Juan Miguélez de Mendavía, que después de haber sido fiscal en Logroño entre 1693 y 1696 le perdemos la pista, hasta encontrarlo, entre los miembros del Consejo de la Suprema, hacia $1699^{19}$.

Finalmente, encontramos a quienes el destino no les dejó avanzar más allá del cargo de fiscal, tal y como le ocurrió al ldo.Alonso de Castro y Losada, quien murió en Logroño en 1692, siéndolo, aunque no sabemos desde cuando.

El fiscal, en un principio, era quien en la jerarquía del tribunal tenía el rango inmediatamente inferior al inquisidor, si bien, desde la Real Cédula de 1660, su categoría se equiparó en cuestión de honores, sitiales, cojines, sueldo y emolumentos a la de aquel ${ }^{20}$. La diferencia fundamental entre uno y otro cargo era que mientras el inquisidor detentaba jurisdicción, el fiscal nunca la tuvo.

\footnotetext{
12 A.H.N. Inq. leg. 2220, exp. 33 lb, Logrono 19/2/1699.

13 A.H.N. Inq. leg. 2221, exp. 165, Madrid, 27/1/1700 y leg. 4979, fol. 1r.

i4 A.H.N. Inq. leg. 2222, exp. 6, Logroño 2/3/1709.

15 Cristóbal, A. Confianza,... opus cit. pág. 114.

it A.H.N. Inq. leg. 2221, Madrid 9/10/1700, Logrỡo 19/10/1700, Logroño 2/11/1700 y Logroก̃o $27 / 11 / 1700$.

17 A.H.N. Inq. leg. 4979, fol. Ir.

I* Prado Moura, A. de, Inquisición... opus cit. pág. 68

19 En la relación de miembros del Consejo de la Suprema entre 1666 y 1699 que nos proporcionó MARTiNEZ MILLÁN, J. en «Los miembros del Consejo de Inquisición durante el siglo XVII", en Hispania Sacra, núm. 76, vol. XXXVII, 1985, encontramos a un Juan Miguélez Mendaña, obispo, que a nuestro parecer podria ser el mismo fiscal que sirviera en Logroño años atrás.

20 Lea, H. Ch. Historia.. opus eit, t. II, pág. 99. 
Con todo, de éste dependía en gran parte la responsabilidad del gobierno del tribunal, pues se encargaba del procedimiento procesal en las causas de fe, civiles y criminales. Además, vigilaba la actuación de los inquisidores, se había de asegurar del funcionamiento adecuado de la hacienda y sobre todo, de mantener el contacto directo del tribunal con el Consejo ${ }^{21}$, del que dependía únicamente, aunque en el tribunal actuase de acuerdo a las órdenes dadas por los inquisidores.

En momentos puntuales en los que en el tribunal no habia fiscal o quien ejercía la fiscalía estaba ausente, era el secretario del secreto más antiguo quien asumía este cargo.

En Logroño, cuando ocurrió esto en la etapa que nos ocupa, fue el secretario Miguel Antonio del Busto el que sirvió la fiscalía (ocho veces a lo largo de más de catorce años, según el mismo exponía tiempo después ${ }^{22}$ ).

La elección de quienes iban a ser fiscales debía ser meticulosa pues, como se ha visto, tarde o temprano, su destino final era el de ser inquisidor. De hecho, a los fiscales se les exigían idénticos requisitos que a un inquisidor para lograr su plaza, es decir, ser un eclesiástico, de sangre limpia, buena conciencia y fama, prudente y capaz, de más de treinta años y con formación universitaria, fundamentalmente jurídica. Además, sería preferiblemente una persona con suficiente hacienda y un nivel social que avalase su independencia y ascendencia en el entorno ${ }^{23}$.

Veamos pues, si estos requisitos generales se cumplían o no entre estos hombres que sirvieron al tribunal del Logroño en los albores del siglo XviII.

\section{Los orígenes: extracción geográfica y social}

En numerosas ocasiones desde la instauración del Santo Oficio Moderno en los reinos de la Corona hispánica, se había insinuado lo inconveniente que era para el buen funcionamiento e independencia del Tribunal el hecho de que, tanto sus inquisidores, como sus oficiales fuesen naturales del distrito donde ocupaban su cargo.

21 Lea, H. Ch. Ibidem págs. 99-101; ConTreras, J. El Santo.. opus cil. pág. 308-309; LóPEz VELA, R. «Estructuras administrativas...art. cit. págs. 169-170.

${ }^{22}$ A.H.N. leg.2223, exp. 8 recibida C $25 / 10 / 1717$. Asi lo encontramos sirviendo como fiscal en 1690 por ausencia del titular, A.H.N. leg. 2220 , s/n. Años más tarde, en 1713 , suple de nuevo este cargo por la muerte del inquisidor-fiscal que habia, leg. 2223, exp. 3, T/l.G. 4/3/1713, o bien porque al morir un inquisidor el que queda necesita de un físcal para proseguir las causas, leg. 2223, exp. $7, \mathrm{~T} / \mathrm{C} 7 / 10 / 1717$.

23 A.H.N. Inq. lib. 1234, fol, 432r, Acordada de 10/11/1632 «que los inquisidores y fiscales se ordenen de orden sacro dentro de seis meses, los que no lo estubieren»; fol. $398 \mathrm{v}$, Breve Papal de $14 / 11 / 1516$.

LÓPEZ VELA, R. "Sociología de los cuadros inquisitoriales», en Historia de la Inquisición en España y América, t. II. Madrid: B.A.C. Centro de Estudios lnquisitoriales, 1983, págs. 744-758; Lea, H. Ch. Historia ... opus cit., t. II, págs. 92-95; Contreras, J. El Santo Oficio de... opus cit., págs. 182-186 y 248 .

Hisponia, LVIJ/2, nưm. 196 (1997) $73 !-773$ 
El motivo alegado para justificar esta postura era que, teniendo en el lugar de su naturaleza sus más firmes vínculos familiares, sociales y económicos, se podía dar lugar a situaciones que favorecerían el nepotismo y las arbitrariedades en el funcionamiento del tribunal.

Sin embargo, esta circunstancia no se prohibio de modo explícito hasta un momento tan tardío como el año 1695, cuando Carlos II dispuso que ni los inquisidores, ni los oficiales del Santo Oficio deberían ser naturales de las provincias a las que fueran destinados ${ }^{24}$.

Para entonces, ésta era una costumbre demasiado arraigada en el cuerpo burocrático inquisitorial, como para poder modificarse de algún modo. Además, las intenciones de buscar personas teóricamente independientes para enfrentar el gobierno de los tribunales de distrito, habían chocado, desde un principio con una evidencia práctica, la necesidad de contar con sujetos conocedores del entorno donde iban a trabajar y con un cierto ascendiente en él. Obviamente, el pragmatismo pudo con todo lo demás y desde tiempos muy tempranos parece ser que la estructura de los tribunales de distrito castellanos se vinculó profundamente a la sociedad en la que estaban asentados.

El caso de Logroño es claro exponente lo dicho hasta ahora. Desde sus orígenes estuvo en gran medida ocupado por personas naturales de su distrito. I. Reguera, en su estudio dedicado al tribunal en su etapa de Calahorra, destacaba el hecho de que, ya entonces, una parte importante de sus inquisidores eran originarios de esta zona ${ }^{25}$.

Esta tendencia continuó tras instalarse el tribunal en Logroño, de tal manera que, si bien, algunos de sus inquisidores fueron oriundos de otras tierras, principalmente castellanas, una parte muy destacada de ellos, lo fueron de las tierras dependientes del tribunal ${ }^{26}$.

En el breve espacio de tiempo que va entre 1696 y 1702, nos encontramos con que la mayoría de los inquisidores designados para el tribunal eran oriundos del distrito o bien, de poblaciones limítrofes.

José de Ozcariz era de Lumbier en el reino de Navarra. Jerónimo Ibáñez y Bernardo de la Mata eran naturales de Logroño. De tierras cántabras, concretamente de Escalante, era el inquisidor Juan Antonio de Santelizes y Francisco de Cossio era natural de Potes, en el valle de Liebana, territorio fronterizo entre el distrito de Logroño y el de Valladolid, al que pertenecían esas tierras.

Del resto de inquisidores, aunque su procedencia no consta explícitamente en la documentación manejada, por los lugares donde desarrollaron sus estu-

24 LEA, H. Ch. Ibidem, págs. 94-95.

25 Reguera, I. Inquisición española en el País Vasco. (El tribunal de Calahorra, 1513. 1570).San Sebastián: Txertoa, 1984, págs. 40-41.

26 Cristóbal, A. "La Inquisición de Logroño: una institución de control social, (1530-1614)", en Inquisición española. Nuevas Aproximaciones. Madrid: Centro de Estudios Inquisitoriales, 1987, págs. 128-137; Confianza,... opus cit?, págs. 59-157.

Hixpania. LVIJ/2, núm. 196 (1997) 731-773 
dios e iniciaron sus carreras, podemos asegurar que eran todos castellanos y muy probablemente, naturales de zonas próximas al distrito logroñés ${ }^{27}$.

Así pues, la extracción geográfica de los inquisidores y como veremos, también de los oficiales del tribunal de Logroño, fue, salvo excepciones, siempre la misma, el área del distrito o sus proximidades.

Lo que si varió a lo largo del tiempo fue la extracción social de las cabezas visibles del tribunal.

A. Cristóbal detectó como en el siglo xvI, el origen de los inquisidores de Logroño habfa sido eminentemente rural, pequeños y medianos labradores del distrito, mientras que en el siglo XVII, el predominio estuvo entre los grandes hacendados y miembros de grupos parentales o clientelares insertos en el cuerpo político de la Monarquía, servidores inquisitoriales y miembros de la administración militar, judicial y civil, eso sí, casi siempre procedentes de la zona ${ }^{28}$.

En lo que respecta a la posición social de las familias y linajes de los que fueron inquisidores al final del siglo xVII y primerísimos años del xVIII, la documentación manejada nos ha limitado en extremo, pues al ser fuentes estrictamente inquisitoriales las consultadas, en la mayor parte de los casos, los datos que nos ofrecen respecto a estos hombres se refieren fundamentalmente a su andadura académica y su trayectoria eclesiástica e inquisitorial, ofreciendo solo información muy dispersa de la cuestión que nos ocupa.

Con todo, con lo que hemos logrado conocer por este camino, junto con la bibliografía que toca estas cuestiones, hemos logrado acercarnos a algunos de estos grupos familiares, en concreto a los de tres de los inquisidores oriundos del distrito, Bernardo de la Mata, Jerónimo Ibáñez Zárate y Juan Antonio de Santelizes.

Sus casos, aunque no sean completamente extrapolables al resto, junto con otros datos significativos de los demás inquisidores, que iremos señalando, nos pueden permitir hacernos una idea aproximada de por donde discurrían las tendencias, de qué sectores sociales se nutría la estructura inquisitorial de este tribunal, en la etapa estudiada.

Hidalgos hacendados y ricos mercaderes situados en sectores próximos a la élite de sus lugares, gracias a su riqueza y a una política matrimonial y de alianzas dirigida a unirse con familias de reconocida posición social en el entorno, serían las características que mejor definirían el perfil de las familias de los tres inquisidores que mejor hemos llegado a conocer.

La riqueza de la familia de la Mata, oriunda de Yanguas pero asentada en Logroño, provenía fundamentalmente de las actividades comerciales y fue con Bernardo de la Mata, con quien logró consolidar su status en la sociedad logroñesa, al integrarse éste entre los hidalgos de su élite.

27 Gregorio Ramos realizó sus estudios mayores en Oviedo, Santiago Hidalgo comenzó su formación académica en Burgos y Pedro Nogáles en Salamanca.

28 Cristóbal, A. "La Inquisición de Logroño. art. cit. págs. 13 I-132.

Hispania, LVII/2, nùm, 196 (1997) 731.773 
Abogado de los Reales Consejos, regidor perpetuo de Logroño y hombre de amplia fortuna ${ }^{29}$, Bernardo de la Mata, consolidó su posición y la de su linaje en la sociedad riojana, en primer lugar, al emparentar por vía del matrimonio con la farnilia Gil Blázquez, ricos vecinos oriundos de Yanguas (Soria), con una regiduría perpetua en la capital riojana y después, tras enviudar y ordenarse de sacris, al lograr el honor, prestigio y ascendencia que le concedía el ocupar diferentes cargos y en la organización burocrática de los obispados del distrito y un cargo inquisitorial, como el de fiscal e inquisidor, en su propia ciudad.

Similar trayectoria tuvo la familia Ibáñez Zárate. Vecinos hidalgos de Logron̄o, con cargos de gobierno a nivel local, servicios a la Corona e insertos en la estructura de personal del Santo Oficio, tanto en cargos de distrito, como en el mismo tribunal de Logroño durante varias generaciones ${ }^{30}$, culminaron su ascenso en el seno de la Inquisición con el logro del cargo de inquisidor para Jerónimo.

El padre de este inquisidor había sido regidor de Logroño, como su abuelo, además de Procurador Mayor, familiar y poseedor de una vara de alguacil de la Inquisición ${ }^{31}$. De su misma red parental era la familia Jaca, poseedores de mayorazgo, que contaba con miembros laureados con órdenes militares, destacados cargos eclesiásticos, puestos de relevancia en el gobierno municipal de Logroño y la vara de alguacil mayor del tribunal, desde el siglo XVI ${ }^{32}$.

El curriculum familiar de Juan Antonio de Santelizes avala el hecho de podamos afirmar que pertenecía a un linaje y familia destacados no solo en su lugar de origen, sino extendido hasta las altas esferas de la administración e iglesia del reino.

Su familia era de las principales de Santoña y durante años monopolizaron, avalados por su posición económica y social relevante, los cargos inquisitoriales de distrito en aquella villa cántabra. Contaba con parientes instalados en los niveles más altos de la estructura inquisitorial, un tío inquisidor de Toledo y Zaragoza, Carlos del Hoyo, un primo inquisidor de Murcia y Valladolid que llegó a consejero de la Suprema, Luis de Velasco Santelizes, lo mismo que Antonio Sevil de Santelizes miembro de los Consejos de Inquisición y Castilla, a finales del xvi ${ }^{33}$. Además tenía tíos canónigos en la Santa Iglesia de Toledo y uno arzobispo de Burgos, Joan de Isla ${ }^{34}$.

En el resto de los casos, aun sin saber de modo concreto cual era la posición socio-económica de sus familias, indudablemente el camino y requisitos

29 SáEZ DE OCARIZ y RutZ dE AZÚA, M. «Un apelido ilustre en la historia de Logroño. El apelido De La Mata en los archivos de Santiago El Real», en Berceo, ã̛o XXIII, núm. 79, 1968, págs. 169-19].

30 A.H.N. Inq. leg. 2225, exp. 8, recibido Madrid 14/1/1718.

31 Crtstóbal, A. Confianza., opus cit., pág. 165.

32 Ibidem, pág. 142.

33 Barrios, F. *Relaciones entre Consejos: los consejeros de Castilla en la Suprema. Notas para su estudion, en Perfiles juridicos de la Inquisición Española. Madrid: Instituto de Historia de la Inquisición, Universidad Complutense, 1989, págs. 580.

34 A.H.N. Inq. leg. 2222, exp. 6, 273/1709.

Hispania, LVIL/2, núm. 196 (1997) 731-773 
a superar en el logro de un puesto inquisitorial del relieve del de inquisidor ya revelan de entrada, el hecho de que debian de contar con un linaje de cierta calidad, con una disposición de recursos adecuada y con lazos de amistad o clientelares con suficiente entidad como para lograr su meta en el seno de la Inquisición.

\section{El camino hacia la Inquisición: antecedentes, modos de acceso y tipologias}

La formación universitaria, el ingreso en una Universidad distinguida y más aún, en uno de los Colegios Mayores de Salamanca, Valladolid o Alcalá se erigió en uno de los peldaños a escalar por la gran mayoría de los que pretendiesen seguir una carrera burocrática en la administración española del Antiguo Régimen.

La Universidad y especialmente, los Colegios Mayores fueron los focos desde donde se iniciaban los mecanismos de cierre, selección y presión de aquellos grupos interesados en integrarse en los puestos principales de la Iglesia y la Corona, siendo la Inquisición uno de ellos.

Ser colegial suponía compartir una misma comunidad con aquellos que ocupaban los cargos más codiciados de las altas esferas burocráticas, los de consejeros. La burocracia del Antiguo Régimen se nutría fundamentalmente de estos centros y las relaciones de patronazgo entre los que había sido colegiales y los que lo eran, permitían a unos potenciar su posición y ampliar sus redes de dependencia a través del apoyo a las carreras de sus compañeros y a estos establecer, desde sus Colegios, relaciones ventajosas para su futuro y buscar por este camino el modo de colocarse en los órganos que les interesasen. La Inquisición fue uno de ellos y los inquisidores sus máximos protagonistas.

Exponía R. Kagan en su obra dedicada a la Universidad española en la Edad Moderna que «..era vox populi que el hijo o sobrino de un funcionario del gobiemo que obtenía una beca en un Colegio tenía su futuro politico asegurado..." ${ }^{35}$. El testimonio de Juan Antonio de Santelizes corrobora este hecho, a nivel de Inquisición, en un memorial remitido al Inquisidor General en 1709, cuando explicaba las circunstancias y apoyos con los que se incorporó al Santo Oficio. Decía este inquisidor que "...aconsejado del arzobispo, $\mathrm{mi}$ señor y mi tío y de colegiales de mi casa que en aquel tiempo servian algunos de los primeros empleos de la Corte... ${ }^{36}$, fue cuando decidió buscar su futuro en la Inquisición.

El ser juez inquisitorial exigía ser jurista ${ }^{37}$ y si a esto añadían conocimientos en Cánones y Teología, su idoneidad a nivel académico, como candidato a tal cargo era aún mayor.

3s KaGAN, R. Universidad y sociedad en la España Moderna. Madrid: Tecnos, 1981, pág. 143.

36 A.H.N. Inq. leg.2222, exp.6, año 1709 .

37 LEA, H. Ch. Historia de la ...opus cil., pág. 94. 
Los inquisidores de Logroño fueron todos universitarios, si bien no todos cursaron estudios de Leyes.

Aunque ciertamente, los juristas fueron mayoría y de estos, la mayor parte combinaron estos estudios con los de Cánones, también hubo otros que solo recibieron formación en esta última materia.

Titulado en Leyes encontramos a Jerónimo Ibáñez, con el grado de bachiller por la Universidad de Valladolid. En Cánones estuvieron titulados Francisco de Cossio y Pedro Nogales, que fueron bachilleres por Salamanca y con estos, Bernardo de la Mata, licenciado en la misma materia por Valladolid y Salamanca y doctor por la Universidad de Irache. Por último, el grupo más amplio estaba conformado por aquellos que habían realizado estudios de ambas materias. Santiago Hidalgo fue bachiller en Leyes por Salamanca y en Cánones por Valladolid, José de Ozcariz obtuvo ambas titulaciones con grado de bachiller en Valladolid, Gregorio Ramos las logró en la Universidad de Oviedo y finalmente, Juan Antonio de Santelizes se licenció en Leyes en Salamanca y en Cánones en Avila.

Por tanto, la mayor parte de los casos tratados presentan trayectorias académicas de cierta calidad, aunque los caminos que tomaron posteriormente y las estrategias que pusieron en juego para su acceso a la Inquisición variaron.

En Logroño entre 1690 y 1705 podemos distinguir, por un lado, a un grupo de inquisidores que se ajustarían, en cierto modo, al modelo de inquisidor potenciado en la época del Inquisidor General Arce Reinoso ${ }^{38}$. Esto es, hombres con una formación académica sólida, adquirida en las Universidades y Colegios Mayores de más prestigio de la Corona de Castilla. Eclesiásticos que iniciaron su andadura profesional fundamentalmente en la docencia universitaria y en cargos destacados de la organización burocrática de los obispados, quienes optaron, más tarde, por proseguir sus carreras desde la Inquisición, amparándose en el apoyo y las alianzas que, fundamentalmente, a través de sus parentelas, tenían con la propia institución inquisitorial y con demás cuerpos de poder de la Monarquía Católica.

Por otro lado, aparece un grupo de inquisidores para los que no fue tanto la herencia de servicios y apoyos del linaje, como los propios méritos y servicios personales, los que se vieron recompensados por aquellos o con el apoyo de aquellos para quienes habían trabajado, o sea nobleza, jerarquía de la Iglesia e Inquisición, fundamentalmente.

Entre los primeros encontramos a José de Ozcariz, caballero de la orden de Santiago, que realizó sus estudios mayores en Valladolid, donde opositó a cátedras, lo mismo que en Salamanca, donde obtuvo la beca de voto jurista del Colegio Mayor de San Bartolomé, la cual ocupó durante seis años, desempeñando diferentes labores docentes antes de entrar a servir en el Santo Oficio ${ }^{39}$.

3* López Vela, R, "Sociología de .... art. cit, págs. 764-773.

32 En Valladolid leyó de oposición por dos veces a las cátedras de Digesto Viejo y Clementinas con puntos de veinticuatro horas. En Salamanca presidió dos actos de conclusiones y sustituyó la cátedra de Digesto viejo siempre que șe le ofreció. A.H.N. Inq. leg. 4979, fol. 1v-2r.

Hispania, LVII/2, núm, 196 (1997) 731-773 
También, a Pedro Nogales Dávila, caballero del orden de Alcántara, de cuyo colegio fue colegial en Salamanca, donde realizó sus estudios mayores. Allí mismo, sustituyó durante seis meses cátedras de Código y Digesto viejo, leyó de extraordinario Instituta y presidió dos actos de conclusiones. Fue además, prior de la villa de Rollán y juez ordinario en la parroquia de La Magdalena ${ }^{40}$

Como ellos, Juan Antonio de Santelizes, quien estudió en Avila y Salamanca, donde fue colegial mayor del Colegio de San Bartolomé, por dieciséis años, siendo colegial huésped y en los últimos años Decano, para luego pasar a ocupar diferentes cátedras en la facultad de Cánones de esa misma ciudad. También fue maestre escuela, dignidad y canónigo de la Santa Iglesia de Bur$\operatorname{gos}{ }^{41}$.

Y por último, se ajustaría al perfil del primer grupo citado, Jerónimo Ibáñez, que estudió en Alcalá, fue bachiller en Valladolid y colegial Mayor por ocho años del Colegio Mayor de Santa Cruz, donde sustituyó cátedras y participó en numerosos actos académicos. Fue además ordinario y provisor en Valladolid durante un año ${ }^{42}$.

Estos dos últimos inquisidores contaban además, con una genealogía cargada de personajes de su parentela que habían prestado servicios a la Iglesia, la Administración y la Inquisición, aunque en cada caso la importancia de sus servicios a una u otra instancia variaron.

En el caso de lbáñez el mayor peso de su cursus honorum lo tenían los servicios de su familia al Santo Oficio, más concretamente, al tribunal de Logroño, aunque contaba también, con antepasados que habian servido al Rey en el ejército ${ }^{43}$. Por la línea paterna, su bisabuelo y abuelo habían sido familiares de Logroño, al igual que su padre, quien también fue alguacil y había servido la vara de alguacil mayor en ínterin durante la minoría de su propietario (1658-1661). Además, en la familia de su abuela paterna contaba con miembros que habían ocupado cargos en el distrito y puestos en este y otros tribunales. Por la línea materna, su abuelo había sido también familiar en Castañares, desde 1641 y coetáneos a nuestro inquisidor, tenían un hermano y un sobrino que eran familiares del número de Logroño.

Nos hallamos así ante un claro ejemplo de un linaje fuertemente vinculado a la organización inquisitorial del tribunal de Logroño. Los Ibáñez Zárate fueron una familia que, generación tras generación, fueron colocando a sus miembros en distintos puestos inquisitoriales y patrimonializando, no

40 Prado Moura, A. de, Inquisición e .. opus cit. págs. 55-57.

41 Leyó catorce veces de puntos, fue catedrático de Decretales Mayores, tuvo las de propiedad de Vísperas, Sexto, Vísperas menos antigua y Vísperas más antiguas. A.H.N. Ing. leg. 4979, fol. $1 \mathrm{~T}-$ v T/I.G. 5/1705 y leg. 2222, exp. 6. PRADO, A. de, Inquisición ...opus cit. p. 52 y 55; M. GarcíaOliva, «Montañeses en la Universidad». XL Aniversario t. I. Santander: C.E.M. 1976, pág. 440.

${ }^{42}$ Durante su estancia en el Colegio de Santa Cruz presidió seis actos de conclusiones, explicó de extraordinario, sustituyó las cátedras de Código más antiguo, Digesto Viejo, Decreto, Decretales y la de Instituta. A.H.N. Inq. leg. 4979, fol. lr, T/I.G. 5/1705.

43 A.H.N. Inq. leg. 2223, exp. 8, recibida Madrid 14/1//718 y T/C 19/9/1715. 
tanto los cargos, como un espacio, una cuota de poder en el tribunal, apoyada fundamentalmente en alianzas matrimoniales con otras familias insertas también en la estructura del Santo Oficio. Un grupo familiar cuyo empeño, podríamos decir que, culmina en primer lugar, con el logro de la plaza de inquisidor para uno de sus miembros y después, con su paso del tribunal de Mallorca al de Logroño. Ocupando Jerónimo el puesto de máxima autoridad en este tribunal, los Ibáñez Zárate podrían ejercer una gran influencia en el entorno donde se movían sus intereses parentales y centralizar a su alrededor una clientela que les posicionaría con más solidez en la esfera de poder local.

En el caso de Juan Antonio de Santelizes, su curriculum venía avalado, como se ha indicado líneas atrás, por la presencia de miembros de su parentela en la alta jerarquía eclesiástica y la Administración, próximos a las fuentes de mercedes y cargos (Rey, Inquisidor General y Consejo). Al entrar en la Inquisición sus preferencias iban por el tribunal de Valladolid o Logroño, donde entró como fiscal en 1699, por ser en estas áreas donde su parentela y patronos detentaban mayor influencia.

En el Santo Oficio también hubo lugar para otros que, no extraídos de los Colegios Mayores, ni con titulaciones y experiencia docente en universidades tan prestigiosas como la salmatina o vallisoletana, orientaron su trayectoria profesional sobre todo, a la Iglesia, para desde ahí incorporarse al entramado inquisitorial.

Algunos de estos desempeñaron paralelamente a sus cargos eclesiásticos, servicios para la nobleza y a menudo se insertaron en la estructura inquisitorial en puestos inferiores, desde donde lograron, con el respaldo de sus servicios y de los apoyos conseguidos a través de ellos, ir escalando peldaños hasta lograr la preciada plaza de inquisidor.

Los curricula de estos no fueron ni tan homogéneos, ni tan meritorios como los de los anteriores y su ascenso en el cuerpo inquisitorial conllevó, en general, mucho más tiempo, tanto que en algunos casos, el cargo de inquisidor de Logroño fue el primero y el último de su vida. Con todo y aunque, en general, sus carreras y servicios fueron de una mediocridad mayor, hubo también entre estos quienes ocuparon cargos muy importantes dentro de la burocracia eclesiástica de los obispados y otros que tras dilatados servicios a la Inquisición en diferentes cargos secundarios, lograron la culminación y compensación de sus carreras previas con un puesto de inquisidor.

Así, el ldo.Francisco de Cossio, que estudió Artes en Santo Domingo de León y Sagrados Cánones en la Universidad de Oviedo y Salamanca, fue, antes que inquisidor, pasante en la Corte y abogado de los Reales Consejos. También, sirvió como asesor general de los Estados del Duque del Infantado y como abogado de cámara y asesor del señor Almirante en el Partido de Siete Campos. También fue visitador general del obispado de León, provisor y vica rio general del arzobispado de Burgos y provisor en Mondoñedo ${ }^{44}$.

44 A.H.N. Inq. leg. 2220 , exp. 331 b, 19/2/1699. 
En su caso, el apoyo de los obispos y nobles a quien sirvió, a través de relaciones de fidelidad, debió de ser su llave de acceso hasta la Inquisición. A los 46 años, Francisco de Cossio entró como fiscal en el tribunal de Logroño y al poco fue inquisidor-fiscal.

La trayectoria del dr.Bernardo de la Mata se ajustaría al perfil de este segundo grupo que hemos clasificado, si bien el suyo fue un caso particular.

Miembro destacado de la sociedad logroñesa, como hemos indicado ya, Bernardo fue regidor perpetuo, abogado de Logroño y de los Reales Consejo. Antes de tomar las órdenes sacras fue un hombre casado y padre de nueve hijos. Una vez viudo tomo estado sacerdotal, se doctoró en Cánones en Irache y se lanzó a la carrera eclesiástica. Fue provisor y vicario general de Calahorra, beneficiado y rector del Cabildo de la iglesia Real de Santiago de Logroño y tuvo los poderes de los ordinarios de Burgos, Pamplona, Calahorra y Tarazona para votar las causas de fe. Además había sido abogado de presos del tribunal de Logroño, donde luego sirvió como consultor. En el año 1700 obtuvo la plaza de fiscal, cargo que sirvió hasta 1710, cuando logró ser inquisidor. Este puesto fue la culminación de su carrera y de su vida, pues solo vivió tres años más después de ocuparlo a la avanzada edad de setenta y tres.

Categoría y calidad reconocida en el entorno donde vivió y desarrolló su carrera, junto con los largos años de trabajo, abnegación y fidelidad demostrada con sus servicios a la Inquisición y una trayectoria ascendente dentro del cuerpo de la iglesia local, fueron las sendas que le llevaron, eso si lentamente, a lo más alto del tribunal ${ }^{45}$.

Por tanto, si bien es cierto que un status y una calidad social reconocida, lo mismo que una formación académica adecuada eran aspectos tenidos en cuenta a la hora de colmar las aspiraciones de un candidato en el cuerpo inquisitorial, también es innegable que sería el hecho de poder presentar una genealogía avalada por servicios propios y de la parentela, tanto a la Corona, como a la Iglesia y a la propia Inquisición, así como el de contar con el apoyo de quienes ocupaban puestos destacados y próximos a las fuentes de mercedes, los factores que facilitarían, en mayor grado, el acceso del pretendiente al cuerpo deseado.

El patronazgo de miembros de la élite social, política o económica en el entorno local, regional o del reino era clave tanto para ingresar, como para ascender en el seno de la Inquisición. Nobles y altos cargos eclesiásticos colocaban a sus peones allí donde sus intereses más favorecidos podían verse. La Inquisición era uno de ellos. A través de sus vínculos familiares, parentales, de amistad o de interés común, los grupos clientelares extendían su radio de influencia por los escalafones de la estructura interna inquisitorial y con ello su poderío y prestigio. De este modo, el inquisidor, apoyado por otros más influyentes y poderosos que él, a su vez apadrinaría a otros por debajo de él, fortaleciendo así su propia situación y la del grupo o grupos a los que perteneciera. Desgraciadamente, en nuestro caso, debido a la brevedad del tiempo

45 A.H.N. Inq. leg. 4979 , fol. $2 \mathrm{r}$; lb. 1272, fol. $381 \mathrm{v}-382 \mathrm{r}$.

Hispania. LVII/2, nim. $196(1997) 731-773$ 
estudiado y limitados por la fuentes empleadas, la localización de las redes clientelares formadas entorno a los inquisidores o en las que se insertaron al ocupar sus puestos no ha sido, de momento, factible.

\section{Logroño en la trayectoria de sus inquisidores}

Una vez situados nuestros jueces en el tribunal de Logroño, La cuestión siguiente a plantearnos sería cuál fue su trayectoria dentro de la institucion y qué papel jugó su estancia en Logroño en la evolución de sus carreras.

En general, para los inquisidores, una vez logrado el puesto más alto del escalafón burocrático de un tribunal de distrito, el objetivo primordial de sus carreras era lograr ejercerlo en aquellos tribunales que más les beneficiasen y prestigiasen dentro y fuera de la Inquisición.

En la mayoría de los casos, las aspiraciones de los inquisidores se dirigían a conseguir desempeñar sus cargos en los tribunales más reputados y codiciados de la Corona, es decir Toledo, Valladolid, Granada o Sevilla, para desde ahí lograr una plaza en el Consejo de la Suprema o bien, enlazar con otros cargos tan apetecibles a más que aquellos, en la alta administración o en la Iglesia ${ }^{46}$.

Sin embargo, no para todos los inquisidores ésta fue la meta final de sus carreras inquisitoriales. Hubo algunos que, una vez logrado el cargo, su máxima aspiración parece ser que fue servirlo en lugares próximos a su tierra o alli donde sus apoyos y lazos familiares y clientelares fueran más sólidos.

Para los primeros Logroño fue, puestas en juego sus estrategias, influencias y relaciones, la plataforma desde donde dar el salto hacia mejores y más reconocidos puestos, tanto en tribunales más considerados, como en el anhelado Consejo, que les acercarían o encumbraría a las esferas de poder con las que más les interesaba entrar en contacto directo.

Para un gran número de estos inquisidores, Valladolid fue el destino siguiente a Logroño. El dr.d.Gregorio Ramos pasó en 1698 a esa Inquisición, lo mismo que Pedro Nogales. Este inquisidor había sido fiscal e inquisidor del tribunal de Barcelona por cuatro años, después pasó a Logroño por espacio de diez y de aquí fue a Valladolid, para luego llegar a ser consejero de la Suprema, donde se jubiló en $1707^{47}$.

También, Juan Antonio de Santelizes y Santiago Hidalgo pasaron a ese tribunal castellano, aunque las circunstancias que rodearon a estos dos casos merecerán que nos detengamos en ellos con un poco más de detalle, más adelante.

Otros pasaron a otros tribunales tan reputados y deseados como el vallisoletano, desde donde también pudieron, en algunos casos, llegar a la Suprema. El ldo. Cossio que comenzó su andadura inquisitorial en Logroño, pronto fue

46 LóPEZ VELA, R. «Sociología de... art. cit. págs. 687-688.

47 CRISTóbal, A. Confianza... opus cit., págs. 116-117.

Hispania, LVIl/2, nu่m. 196 (1997) 73!-773 
ascendido al codiciado tribunal de Corte, antesala del Consejo ${ }^{48}$ y José de Ozcariz pocos años despuésde ser inquisidor en Logroño, pasó a Granada, para tiempo después, encontrarlo firmando como miembro del Consejo de Inquisición ${ }^{49}$.

Por su lado, Juan de Argaiz, de quien solo sabemos que había ocupado un cargo de hacienda en Córdoba (superintendente de las Arcas ${ }^{50}$ ) anteriormente a su andadura en Logroño, llegó a ser consejero de la Suprema hacia $1699{ }^{51}$.

Así pues de los nueve inquisidores que sirvieron en Logroño entre 1690 y 1705, siete mejoraron desde ahí su posición, al ocupar sus cargos en tribunales de mayor prestigio que les ofrecían mayores posibilidades promocionales, tanto que al menos en tres casos les encontraremos años después formando parte del Consejo de la Suprema.

La trayectoria más generalizada era por tanto, ir acercándose desde tribunales periféricos a otros más reputados, para desde ahí impulsar sus carreras en la dirección que más les conviniera.

La particularidad a la que nos referíamos en el caso de Juan Antonio de Santelizes, está relacionada con este asunto, pues este inquisidor pretendió, quizás envalentonado por el peso de su parentela en la estructura burocrática inquisitorial, romper la dinámica mencionada y saltar directamente desde su cargo en Logroño hasta el Consejo.

Ya cuando Santelizes entró en la Inquisición, se le ofreció el ir a servir la plaza de fiscal a Granada, donde las posibilidades promocionales eran inmejorables, pero sorprendentemente rechazó tal propuesta, prefiriendo servir en Logroño o Valladolid, por estar estos tribunales situados en la zona de donde procedía y donde podía esperar más arropado y cómodo el ascenso que deseaba, que no era otro que el mismo Consejo. Al poco de incorporarse a su plaza en Logroño se le planteó la posibilidad de promocionar al tribunal de Toledo, pero de nuevo rechazó tal ascenso, alegando ser esa ciudad contraria a su salud y lo que parece más relevante, por no contar allí ya con pariente o paisano alguno. En 1709, sin embargo solicitó al nuevo Inquisidor General, Antonio Ibáñez de la Rivaherrera, que le tuviera presente en los nombramientos de consejeros, dejando claro en su memorial como, en caso de no obtener la gracia deseada, no deseaba servir en otro tribunal que no fuera el de Logroño ${ }^{52}$. Poderosas razones y fuertes intereses le debían de atar a este tribunal, para no desear moverse de él si no era para pasar a lo más alto de la jerarquía inquisitorial. Su trayectoria tal y como se ha planteado, parece querer romper el modelo de cursus honorum seguido hasta entonces por la generalidad, el ir ascendiendo de tribunales más lejanos a otros más próximos a la dirección

\footnotetext{
48 A.H.N. Inq. leg. 2221, Logroño 21/9/1700.

49 A.H.N. Inq. leg. 2222 , exp. 2 ; en leg. 2224 y 3680 , exp. 52 y 60 , año 1720 aparece un $J$. Ozcariz en el Consejo.

50 A.H.N. Inq. leg. $2220, \mathrm{C} / \mathrm{T} 16 / 1 / 1698$.

si En A.H.N. Inq. leg. 2220, Madrid 10/1699, aparece su firma como consejero de la Suprema y Martinez Millán, J. en *Los miembros del... art. cit., pág. 421 lo cita como tal,

52 A.H.N. Inq. leg. 2222, exp. 6, Logroño 2/3/1709.
} 
inquisitorial, para desde ellos lograr su acceso al Consejo. Sin embargo, con ese memorial y sus contactos no logró su objetivo principal, sino como el resto, dar un paso más en su carrera pasando a Valladolid en $1710^{53}$.

El otro tipo de trayectoria que habíamos detectado entre el grupo de inquisidores de Logroño se definiría por el hecho de tener en este tribunal la meta, el objetivo final deseado, de tal manera que una vez asentados allí donde querían, en su tierra, permanecerían sirviendo su plaza y ejerciendo el poder que ésta les concedió hasta el fin de sus días.

Tal fue el caso como ya se indicó líneas atrás del dr. de la Mata, para quien Logroño fue su primer y último destino como inquisidor. Y lo mismo ocurrió con su paisano, el inquisidor Ibáñez, para quien el lograr ejercer en el tribunal de Logroño, debió de suponer la culminación, no solo de las aspiraciones propias, sino de las del grupo familiar al que pertenecía. De hecho, Logroño fue su último destino, sirvió en el tribunal quince años hasta que murió en 1717 y no hemos encontrado en la documentación queja alguna por su prolongada permanencia, ni peticiones de traslado. Desde luego parece que su situación satisfizo todas sus aspiraciones.

Retomando un poco el asunto de la naturaleza y vinculación de los inquisidores al territorio donde ejercían su jurisdicción y al hilo de estos dos últimos casos, no parece poderse deducir que a la dirección inquisitorial le preocupase en realidad, evitar esta cuestión. Permitiendo estancias tan prolongadas como la de Ibáñez en el tribunal de su ciudad natal, nada sería menos de esperar que la consolidación de los vínculos establecidos fuera y dentro del tribunal que presidía y menos aún, que no se produjeran irregularidades y arbitrariedades por su parte, favoreciendo intereses personales o parentales, por encima de los de la propia institución. En este sentido, Consejo e Inquisidor General se presentan más que como parte a interferir en esta dinámica, como parte interesada de ella o al menos firme consentidora.

Hasta ahora, los traslados de un tribunal a otro que hemos estudiado se han referido siempre a una mejora de la situación inicial o al fruto recibido tras unos servicios merecedores de recompensa. Sin embargo, la promoción y ascenso no fueron el único motivo del paso de un inquisidor de un tribunal a otro. Hubo casos, en los que el traslado fue la consecuencia de la decisión de la dirección inquisitorial de sancionar una actitud o actividad contraria a lo esperado de sus cabezas visibles en los distritos.

Según, H.Ch. Lea el Consejo tenía dispuesto castigar las conductas inadecuadas de los inquisidores, en principio, con amonestaciones y si a pesar de todo, alguno demostraba ser incorregible podía llegar a ser suspendido por uno o dos años, aunque lo más normal era que fuera trasladado a otro tribunal de inferior consideración ${ }^{54}$. Esto fue, precisamente, lo que le ocurrió al inquisidor Hidalgo.

53 Prado Moura, A. de, Inquisición e.. opus cit., pág. 63.

\$4 LEA, H. Ch. Historia de la. opus cit, t. II, pág. 83.

Hispenia, LVIL/2, núm. 196 (1997) 731-773 
Este hombre había ido ascendiendo lentamente desde el puesto de fiscal en el tribunal de Mallorca, que ocupó durante doce años, hasta el de Valladolid, pasando un período intermedio de dos años en Logroño ${ }^{55}$. Siendo fiscal en aquella ciudad logró en 1698 el nombramiento de inquisidor, pero lejos de ver satisfechas sus expectativas, las encontró frustadas cuando el Inquisidor General Rocaberti le ordenó pasar, ya como inquisidor, al tribunal de Córdoba, donde al parecer había una gran complicidad y necesitaban personal. Para Hidalgo, el ascenso de fiscal a juez era, en estas circunstancias, más un motivo de descrédito que de promoción, pues se le pasaba de un tribunal de la categoría del de Valladolid a otro inferior y alejado de sus círculos. Por todo ello alegó mil excusas para no cumplir la orden del Inquisidor General. Motivos de salud, de dinero, y sobre todo, el deseo de proteger su prestigio fueron los motivos aducidos ${ }^{56}$, pero la respuesta del Inquisidor General a su desacato fue la orden de que pasase en el plazo de veinte días a Logroño.

Tal situación de "castigo" duró aproximadamente dos años, finalizando al producirse un cambio en la dirección inquisitorial, la llegada de un nuevo Inquisidor General y la consiguiente renovación e innovación de las fidelida. des tejidas desde la cabeza inquisitorial. Así, recién entrado el Inquisidor General Mendoza y Sandoval, el ldo.Hidalgo envió sendos memoriales al Consejo e Inquisidor General, exponiendo lo injusto del proceder anterior y solicitando su vuelta a Valladolid. Parece ser que sus ruegos fueron escuchados pues a mediados de 1700 su nombre deja de aparecer en la documentación del tribunal de Logroño y nos consta que pasó a Valladolid ${ }^{57}$.

Resumiendo todo lo tratado hasta ahora, los inquisidores que ocuparon el tribunal de Logrono a finales del siglo XVII y principios del xviI podrían ser definidos a grandes rasgos como eclesiásticos castellanos, originarios del área o las proximidades del distrito del tribunal, cuyas familias detentaban la calidad social, el poder económico y los apoyos y servicios suficientes como para orientarlos sus carreras hacia el mundo de la burocracia de la Corona y la Iglesia, desde donde se integraron en la Inquisición.

Muchos de ellos se formaron en las universidades más prestigiosas de la Corona de Castilla y fueron miembros de los Colegios mayores de más raigambre. Algunos iniciaron su andadura profesional desempeñando actividades docentes en la universidad y otros con una carrera de servicios y eclesiástica, más o menos prolongada y de cierto nivel, aunque siempre en un ámbito próximo a su lugar de origen, para después todos ellos incorporarse al cuerpo inquisitorial.

En definitiva, un nivel de formación académica aceptable, calidad, cierto status y ascendencia en su entorno, pero sobre todo herencia y servicios a gru-

is Cristóbal, A. Confianza.. opus cit, pág. 114.

S6 A.H.N. Inq. leg. 2221, Logrono 2/1/1700 y Madrid 9/4/1698.

57 Aunque no tenemos documentación explicita al respecto, nos consta que efectivamente volvió a Valladolid, pues en estos mismos años, de Prado Moura en Inquisición e..opus cit., pág. 64 y 224, menciona a un inquisidor Hidalgo sirviendo en ese tribunal, 
pos de poder que les tutelaban, Corona, Iglesia e Inquisición, se evidencian como las principales estrategias que hacían funcionar los mecanismos de reclutamiento de las cabezas visibles del cuerpo inquisitorial a finales del xvi y como las características que conformarían el perfil del inquisidor que sirvió en Logroño en estos años.

\section{Los oficiales inquisitoriales en el tribunal de Logroño}

Los inquisidores y fiscales eran asistidos en su actividad cotidiana por un número variable de personas que, bien ocupaban un cargo fijo, con su correspondiente salario o que, simplemente asistían al tribunal cuando sus servicios eran requeridos. El Inquisidor General o el Consejo, en sede vacante, nombraba a los primeros (alguacil mayor, secretarios del secreto, de secuestros, portero, nuncio, alcaide de las cárceles secretas...) y los inquisidores del distrito al resto.

Los de los oficiales eran cargos que tenían una misma categoría administrativa y sus titulares disfrutaban de los mismos privilegios jurisdiccionales y fiscales, pero no, sin embargo, de igual reconocimiento social.

La preeminencia y el prestigio social inherente a cada cargo no estaban relacionados tanto con la importancia del trabajo que desempeñasen, como con las posibilidades que ofreciesen para asentar y mejorar sus relaciones sociales y de poder.

$\mathrm{El}$ alguacil mayor y los secretarios del secreto eran los puestos que conferían mayor dignificación social y en el caso de los segundos, su reconocimiento era paralelo a la importancia que las tareas que desempeñaban, tenían para el funcionamiento cotidiano del tribunal ${ }^{58}$.

El número de los oficiales que componían la estructura burocrática de un tribunal de distrito fue, lo mismo que en el caso de los inquisidores, objeto de continua preocupación para la Inquisición y la Corona.

La aguda crisis económica que, desde antes de mediados del xvi, venía padeciendo el fisco inquisitorial, obligó a la Corona, de quien dependía esta cuestión, a enfrentarse a la búsqueda de soluciones a tan caótica situación financiera. En esta cuestión contó siempre con la estrecha colaboración del Consejo de la Suprema y a veces, con la del Inquisidor General de turno, según la fluidez de relaciones que mantuvieran una y otra instancia de poder.

Entre las medidas tomadas una de las principales y la que una mayor repercusión tuvo sobre la estructura burocrática inquisitorial, fue la de reducir el número de sus componentes a términos racionalizados y coherentes con las necesidades de cada tribunal. Un número inadecuado de ministros dependientes de los tribunales provocaba, además de gastos insoportables, disfuncionalidades e irregularidades que afectaban al cumplimiento efectivo

58 LEA H. Ch. Historia de ...opus cit., págs. 101-102; ConTreras, J. El Santo Oficio de...opus cit., págs. 309-310; LÓPEZ VELA, R. «Estructuras administrativas....art. cit., pág. 170.

Hispania, LVII/2, nủm. 196 (1997) 731-773 
de las tareas asignadas a estos cargos y al funcionamiento general de la Inquisición.

Junto a esto se buscó la recuperación del control de la dirección inquisitorial sobre su personal y de la efectividad en su funcionamiento a través de una elección más cuidada de los pretendientes y de sus nombramientos.

Los Autos de Buen Gobierno de 1629 y 1638 establecieron en cuatro el número de secretarios del secreto adecuados para el tribunal de Logroño y como vemos en la tabla que sigue, a mediados del XVII, tal era el número de ministros que había, con lo que la planta ideal se cumplía en este tribunal.

De hecho, en esta etapa de recortes de personal, el tribunal de Logroño no fue un tribunal problemático al respecto, a pesar de ser excedentario, pues lograron que se recibieran casi todas las designaciones propuestas a la dirección inquisitorial ${ }^{59}$.

En 1677 se dispuso una nueva reducción de personal que dejó el número de secretarios de Logroño en tres y aunque en todo momento hubo más ministros en el secreto de los que dispuestos, nunca más de tres fueron los titulares, siendo el resto cargos honorarios.

PLanta del tribunal de logroño:

\begin{tabular}{lccc} 
& 1666 & 1699 & 1705 \\
\hline inquisidor & 2 & 2 & 3 \\
\hline fiscal & 1 & $*$ & 1 \\
\hline alguacil & 1 & 1 & 1 \\
\hline juez de bienes & 1 & - & - \\
\hline secret. secreto & 4 & 4 & 5 \\
\hline receptor & 1 & 1 & 1 \\
\hline contador & 1 & 1 & - \\
\hline secret. secuestros & 1 & 1 & - \\
\hline notario juzgado & - & 1 & 1 \\
\hline alcaide cárceles secretas & 1 & 1 & 1 \\
\hline nuncio & 1 & 1 & 1 \\
\hline portero & 1 & 1 & 1 \\
\hline alcaide penitenciaria & - & 1 & 1 \\
\hline proveedor & 1 & - & $*$ \\
\hline abogado de presos & 1 & 1 & - \\
\hline abogado fisco & 1 & 1 & - \\
\hline médico & - & 1 & - \\
\hline procurador & 1 & 1 & 1 \\
\hline depositario & - & $\mathrm{m}$ & $\mathrm{m}$ \\
\hline Total & 19 & 19 & 17 \\
\hline
\end{tabular}

- vaca; m minoría; * el anterior sirve el oficio

Fuentes: A.H.N.Inq.lib.1323/leg.2220,2/leg.4979,1/

59 LóPEZ VeLA, R. «Estructura y ...art. cit., págs. +166-168, 185-192. 
Recién llegado al trono Felipe V, se constató como la situación funcional y económica de la Inquisición lejos de haber mejorado, había empeorado, llegando las irregularidades a tales extremos que hubo de plantearse una reforma profunda, inspirada en los intentos precedentes.

La primera decisión fuerte se tomó en 1703, cuando Felipe V, tras consultar los efectivos humanos y económicos de los diversos tribunales de distrito ${ }^{60}$, expidió un real decreto por el que se declaraban nulos tanto los cargos honorfficos, como aquellos que no fueran de actual servicio. Además, el monarca dispuso que el Inquisidor General no podría jubilar, ni conceder sueldos, ni ayudas de costa superiores a treinta ducados sin su consulta previa ${ }^{6}$.

Esta disposición solo afectó a Logroño en un caso, reafirmándose así la idea de que este tribunal no tenía una planta considerada sobredimensionada, ni excesivamente problemática .

Tal caso se refería al secretario de secuestros, Andrés de la Pradilla, quien desde el momento de la concesión de la gracia de tal cargo en 1699, ni se habia hecho las pruebas, ni tan siquiera se le había despachado el título, ni tampoco había asistido al tribunal, por estar ocupado en la administración de las aduanas del partido de Badajoz. Al no haber llegado ni a jurar su cargo ni mucho menos a servirlo, su nombramiento acabó por ser anulado a raíz del mencionado real decreto de $1703^{62}$.

\section{Oficiales en el tribunal: diferentes situaciones administrativas}

Siguiendo, en parte, la clasificación que R. López Vela propuso de las diversas situaciones administrativas en las que un oficial inquisitorial podía desempeñar su puesto ${ }^{63}$, para este estudio hemos diferenciado entre los oficiales titulares, los jubilados, los cargos servidos en ínterin o por sustitutos y los oficios acumulados ${ }^{64}$.

La gran mayoría de los miembros del tribunal eran titulares del cargo que ocupaban. El titular de un cargo era aquel que, una vez obtenida la gracia y superadas las pruebas de limpieza y demás trámites necesarios, juraba su cargo, comprometiéndose con la institución a cumplir con sus obligaciones y deberes y a cambio, arrogándose los derechos, honores y privilegios que aquel conllevaba. La expedición del título por el Inquisidor General era la formalización final de la relación del oficial con su cargo y con la Inquisición.

60 A.H.N. Inq. leg. 2221, T/C 2/1/1703.

61 LóPEZ VELA, R. «La Inquisición a la llegada de Felipe V. El proyecto de cambio en su organización y bases sociales", en Revista Internacional de Sociologia, núm. 46. Madrid: C.S.I.C. , Instituto de Economía y Geografia aplicada, 1988, págs. 63-123.

62 A.H.N. Inq. leg. 2222, exp. 2, T/I.G. 1703; leg. 4979, T/I.G. 5/1705.

63 LÓPEZ VELA, R. «Estructura y funcionamiento ..art. cit., págs. 196-200.

64 Las cuestiones referentes a los pficios heredados y comprados se analizarán en el apartado dedicado a los modos de acceso y permanencia de los cargos.

Hispania, LVIL/2, лเ́m. 196 (1997) 731-773 
En Logroño, los puestos principales, desde los inquisidores a los de la secretaría del secreto, fueron casi siempre servidos por su titular, salvo raras excepciones. Otros, como el de alcaide de las cárceles secretas, de la penitencia, abogados del fisco y de presos, médico..se comenzaban a menudo a servir por encargo del tribunal, bien mientras se hacian las pruebas del titular o bien, cubriendo vacantes o provisionalmente cuando se necesitaba, Cuando se daban estas circunstancias, el logro del título y la confirmación definitiva de la plaza era un asunto más complicado y en todo caso, posterior en el tiempo, a veces cuestión de años.

Ni siquiera la compra de un cargo en el tribunal suponía el despacho inmediato del título. Así, Isidro Agustín de Adana, depositario de pretendiente por compra efectuada en 1693, no logró la expedición del título por el Inquisidor General hasta 1706, cuando hubo cumplido la edad mínima requerida para ocupar tal cargo ${ }^{65}$.

No siempre ocurrió que los titulares de los cargos los sirvieron, ni siquiera en las secretarías del secreto. Encontramos así casos en los que una vez. logrado un cargo, su titular no lo sirví nunca, tay l como hizo el secretario de secuestros de la Pradilla y como ocurrió con el secretario del secreto Miguel Zorrilla Arredondo, quien tras serle concedido el cargo en octubre del año 1700 , sólo lo sirvió dos días, para luego volverse a su tierra, de tal manera que su nombramiento se dio por nulo y no se le pagó salario alguno ${ }^{66}$.

Con todo, lo más común era que cuando el titular de un cargo no pudiera servirlo, por el motivo que fuera, se designaran a personas para que, temporalmente o de modo permanente, suplieran sus faltas, sin que por ello, los primeros hubieran de perder los privilegios y beneficios que les concedía su titularidad.

En Logroño, el modo de suplir estos vacíos era bien nombrando cargos en ínterin o cubriéndolos a través de sustitutos permanentes o temporales, recayendo normalmente tanto unos, como otros en gentes previamente vinculadas al tribunal, sobre todo de su estructura de distrito.

Fue en los oficios vendidos donde las tenencias de cargos en ínterin se dieron con mayor frecuencia y duraron más tiempo en el tribunal de Logroño. El impedimento para desempeñar el cargo del que se era propietario se refería generalmente a cuestiones relativas a la edad del titular o a su desinterés por desempeñarlo personalmente.

En estos casos era frecuente que fuese el mismo propietario o su tutor y curador quien propusiera a la persona de la que habría de valerse el tribunal mientras ellos no sirvieran, de modo que el Inquisidor General y Consejo simplemente aceptaban lo dispuesto por el propietario. Además, era éste quien recibía los honorarios correspondientes a la plaza que poseía y de quien cobraba el que le reemplazaba.

Así ocurrió con la receptorfa entre 1685 y 1696 y con la depositaría de pretendientes entre 1693 y 1706 . La minoría de los poseedores de ambos cargos

os A.H.N. Inq.' leg. 2222, exp.3, Logroño 4/7/1701; memorial recibido Consejo 15/12/1705; Madrid, 14/4/1706.

66 A.H.N. Inq. leg. 2222, exp. 165; lib.825, fol. 453 ; leg.4979 fol. $3 \mathrm{v}$.

Hispania, LVI1/2, uบ่m. 196 (1997) $731-773$ 
obligó a nombrar a tenientes de estas plazas hasta el momento en que aquellos alcanzasen la edad necesaria para ocuparlas personalmente.

Durante la minoría de Juan Bautista de la Vid, propietario de la receptoría, sirvieron en ínterin Tomás de Padura (1685-1690), comisario de Logroño, José de Amesqua (1691-92), nuncio del tribunal y Martín Antonio de Badarán (1693-96), por entonces secretario de secuestros.

En la minoría de Isidro Agustín de Adana, ocuparon la depositaría, Juan Gómez del Castillo (1693-1705) comisario de El Ciego y Francisco Martínez de la Mata (1705-1706), a su vez propietario de la notaría del juzgado.

Por tanto cuando había algún puesto vacante o bien era servido por un ínterin o también cabía la posibilidad de que el tribunal nombrara a alguien que lo cubriera temporalmente hasta que no hubiera más necesidad de él o hasta que se proveyese un titular, que podía ser la misma persona que se había encargado hasta entonces de el cargo u otra.

Entre los alcaides de las cárceles secretas y de la penitencia de Logroño el modo más frecuente de ocupar ambos cargos fue primero, en ínterin mientras se hacían sus pruebas y después en titularidad. De este modo se integraron en la estructura de personal fijo del tribunal, José Martínez de Buxo y Tomás Fernández de Esquide ${ }^{67}$, ambos alcaides de las cárceles secretas, primero en ínterin sin pruebas y después con ellas y con título del Inquisidor General.

Sin embargo, no siempre funcionó esta dinámica y hubo casos en los que el nombramiento en ínterin no fue el camino hasta la titularidad del cargo desempeñado. Matías de Pedroso Calderón se encargó de la alcaldía de la penitencia en 1705 y después entre 1711 y 1725, pero no logró la plaza en titularidad, a pesar de sus dilatados años de servicios en el tribunal, por no contar con medios suficientes para costearse las pruebas como para oficial ${ }^{68}$.

Hubo cargos respecto a los que el tribunal o la propia dirección inquisitorial no consideraron necesaria la designación de una persona que lo desempeñasen de un modo permanente, de manera que lo que se hizo fue llamar a personas que lo sirviesen sólo cuando sus funciones fueran requeridas por el tribunal. El caso más notorio se dio entre los abogados del fisco y de presos, cargos que, desde 1704 hasta casi mediados del siglo, no se proveyeron en titularidad, por no considerarlo imprescindible, valiéndose el tribunal de abogados, de entre los de Logroño, que los sirvieron solo cuando fue necesario ${ }^{69}$.

En otras ocasiones, hubo puestos para los que además del titular, se nombraba a otro oficial responsable de cubrir las ausencias y enfermedades del primero. Estos formaban parte del personal de pleno derecho del tribunal, con nombramiento del Inquisidor General y en algunos casos ésta fue la vía por la que accedieron a la titularidad de la plaza servida.

67 A.H.N. Inq. leg. 2221, exp.165, año 1700; lib.482, fol.19.

6.8 A.H.N. Inq. leg. 2224, T/I.G. 29/10/1720.

69 A.H.N. Inq. leg. 2227, Logrofio 30/10/1734.

Hispunia, LVII/2, nùm. 196 (1997) 731-773 
Las ausencias y enfermedades del secretario de secuestros, de la Pradilla, las tuvo Bernardo Antonio Zenzano, comisario de Logroño, desempeñando tal puesto entre 1700 y 1705, al no asistir el titular, sin que al final lograra la titularidad de él ${ }^{70}$. Por esos mismos años, entre 1700 y 1704 , tuvo José Delgado ", las ausencias, enfermedades y futura del abogado del fisco Jacinto Martínez del Barranco, quien por su avanzada edad y achaques no podía desempeñar sus obligaciones de un modo satisfactorio ${ }^{72}$.

Aunque en las Instrucciones de Torquemada ${ }^{73}$ había quedado determinado que un oficial no podía tener dos oficios y dos salarios, no era inusual que un mismo sujeto desempeñase más de un cargo en el tribunal, aunque sólo de uno fuera titular y en circunstancias normales, cobrase un sólo salario.

Ya mencionamos en el capitulo anterior como cuando no se contaba con fiscal en el tribunal, los inquisidores recurrían al secretario del secreto más antiguo para suplir sus funciones.

Su caso no fue el único de acumulación de cargos. Lo mismo ocurrió con el secretario del secuestros Martín Antonio de Badarán ${ }^{74}$ que se ocupó en ínterin de la receptoría o con el secretario honorario del secreto, con José Antonio de Soto Ariz, que se ocupó a la vez de la secretaría de secuestros con salario completo ${ }^{75}$ y con el notario del juzgado, Francisco Martínez de la Mata, que fue a un mismo tiempo, depositario y receptor en interin. También el nuncio José de Amesqua ocupó en ínterin la receptoría y en la mayoría de los casos, los alcaides de la penitencia eran, adernás, proveedores de presos.

Así pues, parece que el tribunal de Logroño procuró cubrir sus necesidades de personal más inmediatas con los ministros de los ya disponía, más que a incorporar nuevos elementos en su planta.

En general, estos oficios desempeñados paralelamente correspondieron a funciones semejantes, a excepción del caso del nuncio que administró la receptoría, pues ambos puestos no tienen ninguna relación entre si, ni funcional, ni de categoría. En este caso su hacienda acomodada ${ }^{76}$ debió de ser la cuestión más considerada a la hora de otorgarle el ínterin de receptor.

Durante el período que nos ocupa no tenemos noticia de que nadie se jubilase en el tribunal, pero sí pocos años más tarde. En los casos hallados fueron los propios oficiales quienes solicitaron su jubilación y negociaron las condiciones de ella, es decir, quienes propusieron quien les sucedería en el cargo, siempre parientes próximos y en que términos económicos y de obligaciones hacia el tribunal, se retirarían ${ }^{77}$.

70 A.H.N. Inq. leg. 2221, exp. 165 ; lib.825, fol. $457 \mathrm{r}-\mathrm{v}$.

$7 t$ A.H.N. Inq. leg. 2221, exp. 18a,b,; lib.825, fol. 486r.

72 A.H.N. Inq. leg. 2221, exp. 18 a.

73 López Vela, R. «Sociología de los cuadros... art. cit. págs. 783-784.

74 Este fue secretario titular de secuestros entre 1685 y 1699 , para luego pasar a ocupar la secretaría del secreto. A.H,N. Ing, leg.2221, 2/1/1700 y T/C 26/1/1700.

75 A.H.N. Inq. leg. 2221, exp.165, recibida Madrid 24/1/1700; leg. 2222, exp. 2, recibida Madrid 6/6/1705.

${ }_{76}$ Cristóbal A. Confianza,...opus cit. pág. 154.

77 López Vela, R. "Estructura y ... art.cit., págs. 196-197. 
Los dos secretarios del secreto más antiguos en 1717, Miguel Antonio del Busto ${ }^{78}$ y José Vélez de Vergara ${ }^{79}$, fueron quienes pidieron su jubilación, proponiendo a su sobrino e hijo respectivamente como sucesores en su cargo y solicitando el mantener su salario completo y la ayuda de costa tras dejar de servir al tribunal. Un año después de su primera petición, el Consejo y el Monarca hicieron gracia de jubilarles, con salario y ayuda de costa ordinaria y en el caso de del Busto, bajo la condición de que siguiera asistiendo al secreto cuando fuera necesario. El sobrino e hijo de estos lograron además incorporarse a la estructura de personal del tribunal, con lo que todas las condiciones exigidas por los dos oficiales fueron satisfechas por sus superiores.

Otros oficiales no tuvieron tanta suerte, Bartolomé de Marigorta, secretario del secreto entre 1697 y 1699, decía en un memorial que su paso al tribunal de Logroño se había debido a su deseo de acercarse a su tierra para jubilarse, pero que no lo había hecho por no ver seguro que cobraría lo asignado ante la situación del fisco del tribunal ${ }^{80}$. Murió en 1699, sin lograr su deseo final.

Con todo, lo más habitual era que el oficial muriese sirviendo su cargo y disfrutando de los beneficios que su desempeño le reportaba hasta el último momento.

Otro tema es el del absentismo de los oficiales, es decir la ausencia de aquellos cuyas obligaciones ajenas al tribunal les llevaban a no asistir regularmente al tribunal o que simplemente no atendían sus cargos con la asiduidad que debían.

En caso de que un ministro necesitara dejar su puesto para trasladarse fuera de Logroño, habla pedir previamente licencia al Inquisidor General, quien una vez consultados los inquisidores, la concedía o no.

Para facilitar la concesión el oficial a veces, incluso proponía un sustituto adecuado y recurría a la ayuda de sus patronos para presionar en el logro de su petición.

Martín Antonio de Badarán, por ejemplo, faltó muy a menudo del tribunal y le encontramos frecuentemente solicitando dispensa de asistencia al secreto o licencia para ausentarse de Logroño, alegando motivos como su mala salud 81, tener que acudir a los ayuntamientos de tabla y extraordinarios al ser regidor perpetuo y preeminente de Logroño ${ }^{82}$ o tener que asistir a los Condes de Aguilar, a quienes servía en la administración sus estados en la Rioja ${ }^{83}$. En este último caso encontramos al Conde de Frigiliana, padre del Conde de Aguilar, virrey de Valencia, Consejero de Estado y miembro de la Junta de 1696, intercediendo ante el Inquisidor General, para que le concediera a Badarán la licencia de ausencia que solicitaba por necesitarlo su hijo para su

\footnotetext{
78 A.H.N. Inq. leg. 2223, exp. 8, memoriales recibidos en Madrid 25/10/1717 y 5/1738.

79 A.H.N. Inq. leg. 2223, exp. 8, memorial recibido en Madrid 2/6/1718.

80 A.H.N. Inq. leg. 2220, exp. $259 \mathrm{~b}$.

81 A.H.N. Inq. leg.222], exp. 165, recibida Madrid 28/3/1700.

82 A.H.N. Inq. leg.2222, exp. 2 recibida en Madrid 5/6/1705.

83 A.H.N. Inq. leg.2222, exp. 2, recibida Madrid 17/10/1705, 23/271706; leg. 2222, exp. 3, Madrid 15/5/1706, Logroño 31/7/1706.
}

Hispania, LV!I/2, núm. 196 (1997) 731-773 
servicio y también, para que aceptase a Bernardo Antonio Zenzano, que servía las ausencia de la secretaría de secuestros, como su sustituto ${ }^{84}$. Sabemos que Badarán consiguió esta vez y casi siempre que lo solicitó, licencia de ausencia. Lo que, sin embargo, no deja claro la documentación es que se nombrase a un sustituto para sus tareas en el secreto y por lo que hemos llegado a conocer respecto al funcionamiento interno del tribunal, pensamos que tal designación no se efectuó, pues nos consta que el tribunal se mostró siempre muy reacio a admitir la entrada en el secreto de personas ajenas a él, aunque fueran miembros del tribunal en otros cargos.

A veces, los oficiales simplemente no asistían al tribunal, sin dar más explicaciones, lo que, si llegaba a oídos de la dirección inquisitorial, provocaba una reprimenda y la llamada al orden correspondiente. Esto fue lo que ocurrió en 1699, cuando el Consejo e Inquisidor General hubieron de advertir a los notarios de secuestros y del juzgado sobre la obligatoriedad que tenían de asistir a sus oficios ${ }^{85}$.

En otras ocasiones, los oficiales se excusaban de su negligencia y pedían un ayudante o sustituto, como hizo Francisco Martínez de la Mata, notario del juzgado, cuando solicitó al tribunal un sustituto en ausencia y enfermedades por hallarse impedido por causa justa. En su caso, el tribunal consultó al Consejo y no hemos encontrado noticias de que lograra su pretension ${ }^{86}$.

$\mathrm{El}$ abuso por parte de aquellos que disfrutaron de licencias de ausencia, oficiales e inquisidores, debió de ser notable y en febrero de 1706 el Consejo intentó regular esta situación disponiendo un máximo de 20 días para usar de tal licencia, advirtiendo que en caso de excederse en su término o de irse el ministro sin ella, sería castigado con la suspensión de oficio y salario ${ }^{87}$.

\section{Herencia, patronos y status: algunos mecanismos de ocupación y permanencia en los cargos}

El acceso a un puesto de oficial en la Inquisición, en teoría, no era un asunto sencillo. El pretendiente debía cumplir requisitos como ser natural del reino, discreto y honesto, limpio de sangre, hijo de matrimonio legítimo, estar

${ }^{84}$ A.H.N. Inq. leg.2222, exp. 3, Caspe 15/3/1706.

85 A.H.N. Inq. lib.825, fol. 437, Madrid $4 / 1699$.

86 A.H.N. leg. 2220, exp. 293a.

87 A.H.N. Inq. leg. 2223, exp.3, C/T 2/1706. Dice el Consejo que teniendo noticia de los repetidos abusos dados en las ticencias concedidas a algunos ministros por el Inquisidor General, contra lo dispuesto por cartas acordadas, en perjuicio de la expedición de las causas y negocios pendientes y los que pudieran sobrevenir durante la ausencia, ordenan tras consulta con el Inquisidor General que no usando los ministros de las licencias en 20 días desde la concesión se entienda de ningún efecto y que si pasado su término no se hubieren restituido al ejercicio de sus oficios no se les admita a él ni acuda con el salario sin expresa orden del Inquisidor General y que los ministros ausentes sin licencia o que teniéndola se hubiere cumplido el tiempo concedido el tribunal le notifique que dentro del tiempo que les parezca necesario comparezcan en el tribunal, so pena de que no se les admita al ejercicio de su oficio, ni se lés pague salario.

Hispania, LVII/2, núm. 196 (1997) 731-773 
casado ${ }^{88} \mathrm{u}$ ordenado y con esto, poseer un cierto status económico y social que le permitiese hacer frente a todos los gastos, explícitos e implícitos, que su petición implicaba y que le avalase en el entorno social.

Esta era la teoría, en la práctica todos los requisitos, excepto el de la limpieza, fueron dispensables y el poder del dinero y de las relaciones de parentela y clientela, combinados con otras estrategias, fueron los elementos de mayor peso en las pretensiones logradas ${ }^{89}$.

Siempre era el pretendiente quien solicitaba el cargo a través de memoriales, presentados en el tribunal, al Consejo y por supuesto, al Inquisidor General.

Los servicios prestados a la institución inquisitorial por la familia y el deseo del pretendiente de continuarlos será el argumento más frecuentemente esgrimido por el aspirante en sus peticiones y uno de los más considerados a la hora de conceder las gracias.

Cualquier servicio de la parentela al Santo Oficio era apuntado como propio en el cursus honorum del pretendiente, como un mérito que le hacía más merecedor que cualquiera de un hueco en el Tribunal, como recompensa a su dedicación, lealtad y servidumbre. A menudo los pretendientes a un puesto de oficial eran ya miembros de la organización de distrito, familiares y comisarios que desde esa posición, habían logrado promocionarse en el cuerpo inquisitorial. Así, como familiares encontramos a Juan Manuel de Heredia, secretario del secreto, que lo fue de Jubera, a Martín Antonio de Badarán, secretario del secreto y familiar de Logroño, como el nuncio José de Amesqua, Juan Bautista Aguirre, procurador del fisco y José Martínez de Buxo, alcaide de cárceles secretas. Por su lado, Juan Gómez del Castillo, depositario en ínterin, era comisario de El Ciego, Tomás de Padura, receptor en ínterin, Bernardo de Zenzano, secretario de secuestros en ausencia y enfermedades y Francisco de Sicilia, alcaide de la penitencia, lo fueron de Logroño.

Con todo, las condiciones, mecánica y caminos que hubieron de seguir para conseguir su acceso a los cargos de distrito eran muy similares a los que se les requerían para ingresar como oficiales.

Junto a los servicios prestados a la Inquisición, también se tomaban en consideración, en más o menos según la fluidez de relaciones rey-Inquisidor General, los servicios prestados a la Corona y por último, a la Iglesia.

Aunque desde un principio, estuvo prohibido el nombrar a parientes o servidores de inquisidores y oficiales en un mismo tribunal, pronto la transmisión de cargos de padres a hijos, tíos a sobrinos, hermano a hermano o de suegro a yerno se impusieron de hecho ${ }^{90}$. Esto dio lugar al asentamiento en el tribunal de auténticas dinastías de oficiales que cerraron o dificultaron el paso a elementos ajenos a su parentela o red clientelar.

En Logroño el exponente más claro de este fenómeno es la familia de los Jaca que copó el cargo de alguacil mayor desde antes de asentarse el tribunal

${ }^{88}$ En este caso la esposa debia curnplir semejantes requisitos de limpieza, legitimidad y calidad.

89 López Vela, R. oSociología de..art. cit., en su primer capitulo está dedicado a los mecanismos de reclutamiento del personal inquisitorial págs. 669-696.

90 LEA, H. Ch. Historia de ..opus cit., t. II, pág. 79.

Hispania, LVII/2, núm. 196 (1997) 731-773 
en Logroño o la de los Badarán presentes en la secretaría del secreto desde principios del xvir.

Lo normal era que al jubilarse o morir un oficial su viuda, sus hijos o parientes más próximos solicitasen su cargo y lo habitual era que se les concediese, si no el mismo puesto, otro similar. Muchos son los casos de transmisión de cargos entre miembros de una misma familia que encontramos en esta etapa en Logroño.

Ya se han mencionado los casos de la familia Jaca y Badarán que monopolizaron los cargos de alguacil mayor y una secretaría del secreto desde finales del xVI y principios del XVII, respectivamente. También hemos citado como el secretario Vélez de Vergara, al jubilarse, logró una secretaría honoraria del secreto para su hijo, al igual que su compañero Bernardo del Busto, eclesiástico sin descendencia, quien la consiguió para su sobrino.

Del mismo modo pasó la nunciatura de José de Amesqua a su hijo Zeledonio, al morir aquel en 1709. La familia Arredondo ocupó la portería del tribunal durante al menos un siglo, pasando de Juan de Arredondo, portero y alcaide de la penitencia, a su hijo Tomás en 1687 y después de él, la ocuparía su vástago, Juan Simón, ya en 1743.

Si moria un oficial dejando hijos menores de edad, solían ser sus viudas quienes solicitasen el paso del cargo para alguno de sus hijos. Desde la dirección inquisitorial, al encontrar el óbice de la juventud de los hijos huérfanos de sus oficiales, se les decía a las madres que "se les tendrá presentes" para la plaza de su marido $\mathbf{u}$ otra del tribunal cuando llegaran a la edad requerida y lo cierto es que solían cumplir con su palabra ${ }^{91}$.

Tan asumida estaba ésta cuestión de la transmisión de cargos entre parientes próximos, que cuando en Logroño se proveyó el cargo de contador en Juan de las Heras, quien nada tenía que ver con su antecesor, Martín López de Langariza, se justificaba el nombramiento diciendo que había sido así por no tener aquel al morir, parientes próximos que pudiesen ocupar su cargo ${ }^{92}$.

Así pues, la herencia de los servicios del linaje y de los cargos directamente, fruto del proceso de patrimonialización de los puestos inquisitoriales, se erigieron como uno de los principales mecanismos de acceso a esta institución.

La estrategia matrimonial se empleó también como medio de acceso y promoción dentro del tribunal.

91 Así ocurrió con Juan Bautista de la Vid, propietario de la cuarta vida de la receptoria A.H.N. lnq. lib.821, fol. 27 o con Diego Martínez de Buxo, quien no logró el mismo puesto de su padre, que había sido alcaide de las cárceles secretas, pero si consiguió serlo de las de la penitencia. A.H.N. leg. 2222, exp. 3 .

92 A.H.N. Inq. leg. 2220, exp. 2, año 1695 . Sin embargo de lo dicho pocos años después aparecen varios memoriales de Joan González pidiendo una secretaria honoraria alegando los servicios de su tío el contador Martín López de Langariza, de su padre Tomás González, que fue alcaide de la penitencia y cárceles secretas y de su padrastro Juan Corella Caballero que fue nuncio. La declaración en contra de sus pretensiones por parte del tribunal y el haber sido ignorado a la hora de proveer el puesto de su tio pueden ser síntoma de unas relacionas poco distendidas entre el pretendiente y el tribunal (leg. 2221 , exp. 165, doc.sin fecha y T/C $30 / 1 / 1700$ ). 
Familias, ya presentes en él, se unían entre si o con otras ajenas a este cuerpo pero que detentaban un cierto status social y económico, con objeto unos de asentar y otros de robustecer su influencia y prestigio en la sociedad y dentro y fuera de la institución.

Esta cohesión dio lugar a extensas redes parentales que por uno u otro lado desbordaban el marco del tribunal, vinculándose con otros grupos e instancias de poder, a nivel local, regional y del reino.

Los casos más perceptibles de estas relaciones y uniones se dieron entre los Ibáñez Zárate y los Jaca, miembros de una misma red parental. Lo mismo que los Badarán, de la Mata, y de la Vid que por vía matrimonial compartirían una misma parentela para mediados del siglo xviII.

Frecuente fue también la combinación matrimonio-herencia. De este modo un cargo podía pasar del padre al esposo de su hija mayor como parte de su dote, tal y como ocurrió con el contador Juan de las Heras, que tras morir, su viuda solicitó de inmediato el cargo para el marido de su hija con el fin de que "no salga el oficio de su casa" 33.

En esta misma línea, la transmisión de un cargo podría darse de un primer esposo a su viuda y posteriormente, al siguiente marido que ésta tuviera. Así, el receptor José de la Vid, al casarse en segundas nupcias con Ana Casado, viuda del depositario de pretendientes, pasó a ocupar también este cargo durante un tiempo.

Otro modo de acceso a ciertos cargos fue su compra ${ }^{94}$. Los compradores debían cumplir todos los requisitos de cualquier oficial, más la disposición de un patrimonio saneado.

La riqueza no era el requisito más importante, pero si condición indispensable para acceder al privilegio. En la Inquisición, como cuerpo reproductor de la sociedad estamental en la que estaba inmerso, los mecanismos de cierre al acceso del privilegio fueron fuertes, pero esas puertas cerradas lubricadas por el poder del dinero y empujadas por el apoyo de patronos se abrían a aquellos elementos que podían combinar ambos factores.

En el tribunal la receptoría, la notaría del juzgado y la depositaría de pretendientes fueron los tres cargos vendidos. Estos eran oficios de reconocido prestigio y en el caso del receptor, además, bien remunerado,

Su venta se produjo durante la etapa del Inquisidor General Sotomayor y se efectuó por varias vidas. Los compradores fueron hombres enriquecidos, ajenos hasta entonces al tribunal, que optaron por emplear su dinero en la adquisición de cargos y honores que les permitieran obtener un reconocimiento social parejo a su status económico .

93 A.H.N. Inq. leg. 2222, exp. 2.

94 Nunca se vendieron cargos que implicasen el ejercicio de jurisdicción. LÓPEZ VELA, R. «Estructuras administrativas..art. cit., págs. 175-192. Para venta de cargos vid TOMÁs Y VALIENTE, F. «Venta de oficios públicos en Castilla durante los siglos XVI-XVII» en Gobierno e Instituciones en la España del Antiguo Régimen. Madrid, 1982, págs. 151-177 y "Ventas y renuncias de oficios públicos a mediados del siglo XVI» en Memorias del IV Congreso de Historia del derecho indiano. México, 1976, págs. 725-753.

Hispania, LVII/2, núm. 196 (1997) 731.773 
La receptoría se vendió por cuatro vidas al precio de 40.000 reales a d.Juan Ruiz de Gaceta, pasando de él a la familia de la Vid en las dos últimas ${ }^{95}$.

La notaría de juzgado fue comprada en 1642, por cuatro vidas, por Blas de Miguel ${ }^{96}$, pasando de él a su pariente lejano Martín López de Langariza. Las dos últimas vidas las compró a su vez, Francisco Martínez de la Mata.

Y por último, la depositaría fue comprada por Pedro Viejo en 1641 por tres vidas, de él pasó en 1652 a su sobrino Antonio Blázquez y una vez muerto éste, la heredó su esposa, ocupándola su segundo esposo José de la Vid, receptor, hasta que en 1693, vendieron la última vida a Isidro de Adana por 27.150 ducados de vellón ${ }^{97}$.

La venta de oficios supuso el grado máximo de patrimonialización de los cargos inquisitoriales. Desde el momento de su venta, quien decidía sobre el cargo era únicamente su propietario, lo que provocaba a menudo corruptelas y sobre todo, absentismo y pérdida de control sobre estos integrantes del cuerpo inquisitorial.

El propietario de un cargo podía designar sustitutos en caso de no poder o no querer servirlo personalmente, como ya vimos y además, decidía a quien vender en caso de interesarle.

En teoría, era el Consejo quien negociaba las ventas, pero en la documentación vemos como una vez adquirido el cargo, era el propietario quien pactaba con un segundo o tercer comprador la venta de su cargo en propiedad.

La dinámica era la siguiente: guardando los modos, renunciaban al cargo tanto el propietario, como sus herederos y lo ponían en manos del Inquisidor General y Consejo, pidiendo, en tono humilde, que hiciesen gracia de él a ese otro comprador o "a quien sea más de su agrado", pero añadiendo inmediatamente, como en caso de no proveer en quien se proponía, se reservarían de nuevo el cargo para usarlo a su conveniencia.

Literalmente esto fue lo que ocurrió con la venta a Isidro Agustín de Adana de la depositaría de pretendientes, por parte de Ana Casado y José de la Vid y obviamente, el comprador propuesto por ellos, fue el designado como nuevo depositario por la dirección inquisitorial ${ }^{98}$.

En el logro de una pretensión también tuvieron su peso específico los apoyos y recomendaciones que el candidato tuviese. El interesado, como siempre que se deseaba obtener un ascenso, una licencia o cualquier otra gracia, había de mover todos los resortes que tuviese a su alcance, en busca de apoyos tanto en los ambientes más próximos al Inquisidor General y Consejo, como en el propio tribunal donde intentaba entrar a servir.

En la documentación manejada, no faltan memoriales o cartas pidiendo o dando recomendación a un pretendiente por parte de miembros principales de la sociedad logroñesa. Miembros del tribunal como Juan Manuel de Here-

95 A.H.N. Inq. lib. 821, fol. 27.

96 A.H.N. Inq. leg. 2220, exp. $293 \mathrm{~b}$.

97 A.H.N. Inq. leg. 2222, exp. 3, Logroño, 4/7/1701, 18/8/1701, 16/2/1706, 5/3/1706, Madrid $15 / 12 / 1705$ y $14 / 4 / 1706$.

98 Vid. nota anterior. 
dia, Martín Antonio Badarán o Bernardo Antonio Zenzano contaron con el patrocinio de los Condes de Aguilar y Frigiliana a quienes sirvieron o de quienes fueron súbditos al vivir en sus territorios ${ }^{99}$. José Martínez de Buxo colocó a su hijo Diego como doméstico del Marqués de la Lapilla, siendo éste quien, más tarde, intercedería por él al Inquisidor General para conseguirle un puesto en el tribunal ${ }^{100}$.

También hay noticias de como miembros de la jerarquía eclesiástica ayudaron a sus patrocinados en su camino a la Inquisición. Fr. Pedro Portocarrero, obispo de Calahorra ${ }^{101}$, en 1699 lo encontramos avisando al Inquisidor General de como aplicaría todas las gracias que cupieran a sus recomendados, para luego enviarle una lista de ellos, para que les favoreciera enterándose de su dependencia en el tribunal de Logroño.

En otros casos era habitual que se aludiese a parientes o amigos en la Iglesia que les pudieran avalar en su pretensión, tal y como hizo José Antonio de Soto, con su tío, obispo de Osuna, inquisidor de Toledo y miembro del Consejo de la Suprema ${ }^{102}$. Las relaciones de parentela, amistad y dependencia establecidas con quienes ocupaban cargos en el Consejo o las secretarías eran una baza importante. Domingo de la Cantolla ${ }^{103}$, poderosa figura en la secretaría del Consejo de Inquisición desde finales del xvI y oriundo del distrito de Logroño, prestó su apoyo a algunos de sus paisanos a los que le unía relaciones de amistad, protección y fidelidad.

Cuanto más próximas estuvieran las influencias a la Corte, más posibilidades tendrían los pretendientes a obtener gracias y mercedes. Esto provocó que en no pocas ocasiones, fuera el propio interesado el que se trasladase a la Corte para, desde alli, ocuparse personalmente de las gestiones concernientes a su pretensión. El pretendiente invertía su tiempo y su dinero en este empeño y con frecuencia su modo de actuar a través «de medios poco justificados» dio lugar a que se produjeran graves inconvenientes en el funcionamiento regular de la institución en estas cuestiones. La efectividad de tales medios debió de ser enorme, tal y como reflejan las palabras del propio Inquisidor General Vidal Marín, cuando señala que eran "..tan autorizados y eficaces que no dejan libertad para las provisiones" 104.

Así con el deseo de erradicar el clientelismo y las irregularidades en la provisión de gracias y con objeto de racionalizar la distribución de mercedes y de recuperar su control, la dirección inquisitorial, encabezada por este Inquisidor General, emitió en julio de 1705 una orden para que en todos los tribunales se comunicase que en las pretensiones de los ministros, sus hijos,

99 A.H.N. Inq. leg. 2222, exp. 2 y 3; leg. 2223, exp. 9.

100 A.H.N. Inq. leg. 2222, exp. 2, 26/9/1705.

101 A.H.N. Inq. leg. 2221, exp. 165, en 1699 .

102 A.H.N. Inq. leg. 2223, exp. 6.

103 Domingo de la Cantolla era natural de Liérganes, Cantabria y fue secretario del Consejo para Castilla. En una carta Miguel Antonio del Busto apela a su amistad para lograr influir en el Consejo y lograr su pretensión de colocar a su sobrino en el tribunal (A.H.N. Inq. leg. 2223, exp.8).

104 A.H.N. Inq. leg. 2222, exp. 3, Madrid 7/1705.

Hispania, LVIl/2, núm. 196 (1997) $731-773$ 
hermanos o parientes a oficios de Inquisición o ayudas de costa se remitiesen memoriales al Inquisidor General expresando sus servicios, o los dirigiesen por medio del tribunal, pero sin ir a la Corte, previniendo que no adelantarían nada con su personal solicitud, porque serían menos atendidos en los términos de gracia.

El hecho de que esta orden volviera a reiterarse meses después da clara cuenta de la escasa incidencia que tuvo su cumplimiento ${ }^{105}$.

\section{Sociología del oficial del tribunal de Logroño, 1690-1705}

Con los oficiales la vinculación al territorio dependiente del tribunal de Logroño fue aún más intensa que con los inquisidores, pues por las noticias que tenemos, todos ellos fueron originarios de poblaciones del distrito.

Según los datos que hemos podido recavar, la economía de la mayoría de los oficiales del tribunal se basó fundamentalmente en la explotación de la tierra y en el comercio.

El origen de la riqueza de muchos de los servidores del tribunal estaba en la tierra. En un memorial presentado en 1731 por los ministros asalariados del tribunal, se decía que para mantenerse con decencia, necesitaban todos ayudarse de la granjería de la labranza de pan y vino, por medio de sus criados de campo asalariados. Las familias presentes en el tribunal por estos años eran prácticamente las mismas que las de principios de siglo, con lo que tal información es perfectamente válida para la etapa que nos ocupa ${ }^{106}$.

Pero en no pocos casos eran estos hombres descendientes de familias de comerciantes quienes, a través del caudal adquirido en sus actividades mercantiles, habian comprado tierras y censos, con los que prestigiar socialmente su riqueza. Las uniones con familias de calidad y posición reconocida en el entorno, por matrimonio o por relaciones de patronazgo, la compra de cargos municipales, como regidurías perpetuas y como no, el acceso a cuerpos privilegiados abiertos a su dinero, tal como ocurrió en la Inquisición a mediados del siglo XviI, fueron los escalones a ascender para llegar a la posición deseada, los medios por los que muchos fueron acercándose a los ć́rculos sociales próximos a élite local.

En general, los principales cargos del tribunal, alguaciles mayores y secretarios del secreto, estaban ocupados por familias de ricos hacendados, que contaban con un recocimiento social equivalente a su potencia económica. El mejor exponente nos lo ofrece la familia Badarán, poseedores de gran hacienda, con casa propia y muchas tierras. Su actividad principal era la de cosecheros de pan y vino, tenían criados, se portaban con gran lucimiento ${ }^{107}$ y formaban parte del grupo social dominante en el municipio de Logroño.

\footnotetext{
105 Ibidem.

lot A.H.N. Inq. leg. 2226, Logrofio 19/1/1731.

107 A.H.N. Inq. leg. 2220, exp. 269, recibido Consejo 9/8/1698.
} 
Martín Antonio fue caballero de la orden de Calatrava, regidor perpetuo de Logroño y corregidor de Barbastro y Calatayud.

Sin embargo, el tribunal también aceptó entre sus filas a aquellos que pudieran aportar una solidez económica demostrada, aunque proviniera directamente de actividades menos consideradas como la venta y el comercio.

En la mayoría de los casos los cargos ocupados por este tipo de gente fueron oficios comprados, de tal manera que el dinero poseído por la familia fue su vía de incorporación a la Inquisición. Este fue un fenómeno característico del siglo Xvir, pero su repercusión llegó, al menos, hasta los inicios de la centuria siguiente.

Isidro Agustín de Adana, depositario de pretendientes por compra del cargo, procedía de una familia dedicada únicamente al comercio. Su abuelo paterno había sido mercader con tienda propia, vendedor de aceite de ballena y pescado en Logroño y administrador de una carnicería, al igual que su tío materno, que era también mercader en Logrono ${ }^{108}$.

José de la Vid, casado en primeras nupcias con María Martínez, "mujer muy acomodada", empleó su riqueza en la compra de cargos en el cabildo municipal, una regiduría perpetua y en la Inquisición, la receptoría por dos vidas a Manuel Ruiz Gaceta, hijo del comprador originario que no servía el cargo. Su segundo matrimonio fue con Ana Casado, viuda de Antonio Blázquez y heredera de la depositaria de pretendientes. Con esta unión amplio y consolidó su posición en el tribunal ${ }^{109}$.

Igualmente, Francisco Martínez de la Mata se había dedicado a servir en la tierra de Mariana de Celaya en Logrofio, antes de convertirse en su dueño y en el de su caudal, unos 12 mil ducados ${ }^{110}$. Casado con una mercadera de Logroño del primer crédito, Josefa de Iturzaeta, su caudal saneado y seguro les permitió comprar por dos vidas la notaría del juzgado y hacerse cargo, primero él y luego su esposa, de la receptoría en ínterin durante mucho tiempo.

Vemos pues como amasar un cierto caudal permitió a muchos abandonar actividades económicas poco o nada reconocidas socialmente y cambiar la estrategia familiar de modo que, el origen de su riqueza no fuera obstáculo para poder irse acercando al estamento privilegiado, a través, por ejemplo, de su incorporación a la estructura de personal del Santo Oficio. Así, José de Amesqua, nuncio y receptor en ínterin del tribunal de Logroño, cuando pretendió su cargo se dijo que era mozo de buenas prendas y procedimientos, aunque tenía contra si el haber vivido y trabajado con un tío suyo confitero, aunque estando ya cerrada la tienda y retirado el tío, por tener una hacienda acomodada de la que vivir, el problema de haber ejercido un trabajo vil no evitó el logro de su plaza '"'.

108 Cristóbal, A. Confianza..opus cit., págs. 78-79, 187.

109 CrISTÓBal, A. lbidem., págs. 74-76.

110 Cristóbal, A. Ibidem, pág. 140.

'I CRISTÓBAL, A. Confianza..,opus cit., pág. 154.

Hispania, LVII/2, nủm. 196 (1997) 731-773 
El abandono de una actividad poco considerada, su establecimiento como hacendados y la orientación de los miembros más jóvenes de la familia hacia la carrera burocrática y los cuerpos de honor fue el giro social que dio esta familia, gracias al dinero proporcionado por sus actividades, por muy bajas y viles que fueran.

Hubo también quienes ocuparon cargos en el tribunal que eran pequeños hacendados y labradores, normalmente de los entornos de Logroño, mucho más modestos, pero con lo suficiente para afrontar los gastos de una pretensión y para mantenerse con la decencia que correspondía a un ministro de Inquisición.

Del primer de los Arredondo que entró como portero en el tribunal a mediados del xvir, sabemos que tenía el ejercicio de labrador fuera de Logroño y de los Martínez de Buxo, alcaides de las cárceles del tribunal, que tenían "..bastante hacienda con la que pasar" "12. Actividades y recursos más humildes, en los cargos del tribunal de menor responsabilidad y reconocimiento social.

Por último, podríamos distinguir a quienes ejercieron profesiones liberales, como abogados o médicos, aunque fueron los menos en la estructura de personal del tribunal. Contamos con muy poca información respecto a estos pero a grandes rasgos podríamos decir que debieron pertenecer a familias con una posición social de cierta importancia y una economía suficiente como para afrontar la formación universitaria necesaria para ejercer estas profesiones. José Delgado, abogado del fisco en ausencias y enfermedades y futura entre 1700-1704, señalaba a su ingreso en el cargo que, contaba con casa propia y hacienda en Logroño ${ }^{113}$.

Aquellos que fueron eclesiásticos, normalmente disfrutaron de prebendas y rentas de la Iglesia, junto a su salario inquisitorial y al patrimonio familiar que les avalase.

Miguel Antonio del Busto, secretario del secreto, fue clérigo presbitero y beneficiado en Viana. Tomás de Padura, teniente de receptoría y Francisco de Sicilia, presbitero, capellán y alcaide de la penitencia, eran beneficiados de la Iglesia Imperial de Palacio de Logroño y Juan Gómez del Castillo, depositario en interin y comisario, fue presbitero y beneficiado en El Ciego.

Por otro lado, era frecuente que los oficiales inquisitoriales o sus parientes uniesen a su hacienda la ocupación de cargos destacados en el gobierno municipal o en la Administración y que estuviesen relacionados, por parentela y sobre todo por clientela, con la oligarquía logronesa conformada entorno al Conde de Aguilar ${ }^{114}$ y con elementos próximos al Monarca y la dirección inquisitorial.

Los miembros de las principales familias, de la oligarquía logroñesa no aparecen, al menos en estos años, ocupando puestos inquisitoriales, pero si personas muy próximas a ellos, deudos o familiares suyos, a través de los cuales pudieron continuar su influencia sobre el tribunal.

112 Cristónal, A. Ibidem, págs. 152-153.

113 A.H.N. Inq. leg. 2221, exp. 18a, T/I.G. 16/2/1700.

114 LOREnzo CADARSO, P. L. "Luchas políticas y refeudalización en Logroño en los siglos XVI $y$ xvII $\rtimes$, en Historia Social, núm. 5, 1989, págs. 3-23. 
Había quienes detentaban signos de distinción como ser miembros de ordenes militares. Martín Antonio de Badarán era caballero de Calatrava, Joseph de Soto y Ariz, secretario de secuestros y secreto, de Alcántara

En general, el oficial inquisitorial de Logroño podría ser definido como hombre originario del distrito, miembro de grupos familiares que, bien venían sirviendo en el tribunal diversos oficios de un modo quasi-patrimonial desde hacia generaciones o bien eran nuevos elementos insertos en él, fundamentalmente, a través de su potencia económica.

La mayoría pertenecían a familias con haciendas bastante saneadas, ya fueran heredadas o fruto de actividades mercantiles, que participaban en órganos políticos o eclesiásticos y estaban inmersas en redes clientelares a través de lazos de parentesco, dependencia política y económica, todo lo cual les permitía detentar un status próximo a las élites locales de la sociedad logroñesa del Antiguo Régimen y establecer un marco de relaciones que, favorecido por las prerrogativas y privilegios que les proporcionaba su condición de miembro de la Inquisición, les permitiera la consolidación del grupo en la sociedad estamental en la que estaban inmersos.

\section{CUESTIONES DE hacienda RELATIVAS AL PERSONAL DEL TRIBUNAL}

El capítulo de la hacienda del tribunal más importante en relación con los ministros que allí servían, fue el de los sueldos y ayudas de costa que estos recibían, si bien está claro que su cobro dependía directamente, del resto de las cuestiones hacendísticas, o sea demás gastos e ingresos, del tribunal.

Según J.Martínez Millán, el último tercio del siglo XVI y primero del XVIII constituyó una de las etapas más críticas de la Hacienda del Santo Oficio.

Censos y canonjías fueron las rentas fundamentales de la hacienda inquisitorial y el objetivo primordial de los tribunales fue mantenerlas, pues estas rentas fijas, y no las derivadas de su actuación procesal, fueron las que sostuvieron su hacienda y las que caracterizaron su comportamiento económico its.

El panorama que presenta J. Martínez para el tribunal logronés en esta etapa es de crisis y déficit continuo.

La financiación de este tribunal era eminentemente canonjil, sin embargo, durante la primera mitad del XVII los ingresos por censos y canonjías no consiguieron si quiera cubrir el importe anual de los salarios, por lo que las consignaciones que recibía de otros tribunales no fueron suficientes para que en los balances finales, el alcance no fuese casi siempre contra el receptor:

La crisis de las fuentes de financiación inquisitoriales vino dada por el descenso de los ingresos de las canonjías, por el decrecimiento de las rentas de los censos, al subir la tasa de interés y no pagarse puntualmente los intereses

II5 Martínez Millán, J. "Estructura de la Hacienda de la Inquisición", en Historia de la Inquisición en España y América, t. K, Madrid: B.A.C., 1993, págs. 980-984.

Hispowia. LVII/2, núm. 196 (1997) 731-773 
y finalmente, por las exigencias de la Corona de contribuciones fiscales a la Inquisición cada vez con mayor frecuencia ${ }^{116}$.

El tribunal se mantuvo así en un precario equilibrio económico, amenazado siempre de crisis, por cualquier circunstancia.

La situación se fue agravando a medida que pasaban los años, hasta que en los años finales del siglo xVI, comienza a percibirse una cierta recuperación, expresada en la gran actividad en inversión de censos que tuvo el tribunal ${ }^{117}$.

En la documentación manejada encontramos como, entre 1690 y 1705 la situación del fisco en el tribunal de Logroño era efectivamente, muy precaria. La correspondencia entre el tribunal y el Consejo se refiere continuamente a este hecho. Peticiones de ayudas, reclamos para que les fueran enviadas las consignaciones del tribunal de Granada, quejas por falta de pago de salarios y ayudas de costa a los ministros y las dificultades a la hora de efectuar los cobros de sus fuentes de ingresos son argumentos más frecuentes de tales cartas.

Los ingresos del tribunal provenían inicialmente, de lo que produjeran las canonjías ${ }^{118}$, los censos y los secuestros, junto a los derechos cobrados por papel y fisco y partes de las libranzas de los pretendientes. Sus gastos venían de los pagos de salarios y ayudas de costa, de la alimentación de los presos pobres y de los gastos extraordinarios y los causados en la administración de los canonicatos.

El saldo en todas las relaciones de efectos del fisco halladas para esta etapa, fueron negativos, aun incluyéndose en el apartado de cobros la consignación, o parte de ella, que el tribunal de Granada debía enviarles cada año 119. Esta ascendía a 222.000 maravedies anuales, si bien en estos años, su pago no fue todo lo puntual que se le exiǵá, según el tribunal andaluz por ser muchos los gastos y socorros que tenían que dar a otras inquisiciones, lo que dejaba su fisco muy exhausto 120 .

Estos retrasos provocaron frecuentes reclamaciones del tribunal logroñés 121 siempre necesitado de efectivo que le permitiera sobrellevar su deficit crónico.

116 Ibidem, págs. 1018-1019.

117 Ibidem, págs. 1007-1011, 1039-1040.

118 Canonjías de Logroño: Santo Domingo de la Calzada, Tudela, San Millán de Lara, Briviesca, San Quirce, Covarrubias, Santillana, Vitoria, Nuestra Señora de Alabanza, Santander, Alfaro, Valpuesta, Osuna, Logroño, Calahorra, Cenartuzo y Soria. MARTinez MılLán, J, «Las canonjías inquisitoriales: un problema de jurisdicción entre la lglesia y la Monarquía (I480-1700)» en Hispania Sacra, vol, XXXIV, núm. 69, Revista de Historia eclesiástica de España, Madrid: Instituto Enrique Florez, C.S.I.C. 1982, págs. 9-63.

119 A.H.N. Inq. Leg. 2221, Memorial de lo cobrado y pagado en esta Inquisición desde las cuentas deł año 1701 que fueron las últimas hasta el 28 de diciembre de 1703; leg. 2222, caja $1 \mathrm{~T} / \mathrm{C}$ 30/4/1704; Vid. MARTineZ MilláN, J., "Los cambios en el Santo ..ant. cit. págs. 1370, aparece un batance de la hacienda del tribunal en 1705 , siendo sus ingresos 50.574 reales y sus gastos $58.324 \mathrm{r}$, el saldo negativo ascendia a 7.750 reales.

120 A.H.N. Inq. leg. 2221, exp. 46b, Granada/C 31/8/1700; leg. 2220, exp. 300, Granada/C $21 / 4 / 1699$.

121 A.H.N. Inq. leg. 2221, T/C 8/7/1700, T/L.G. 8/7/1700; lib.825, fol. 466v-467r, Madrid 18/8/1700, fol. 498v-4995, Madrid 28/5/1705; leg. 2222, exp.1, T/C 24/5/1704, T/I.G. 6/6/1704, T/l.G. 5/7/1704.

Hixpania. LVU/2, nu்m. 196 (1997) 731-773 
Las canonjías que fueron la principal fuente de ingresos de la que se nutría el tribunal, también fueron motivo de numerosos enfrentamientos con los cabildos e iglesias que debían satisfacerlas. Su cobro no fue un asunto sencillo y los conflictos estuvieron al orden del día.

En 1700 encontramos al tribunal quejándose de que habiendo pedido certificación a los secretarios de los cabildos de las iglesias donde gozaban de canonicatos, para ver si los administraban o arrendaban, tanto la iglesias de Calahorra, como la de La Calzada y Burgo de Osma se habían excusado de darlas, por lo cual pedían al Inquisidor General que mediase en el problema para evitar inconvenientes mayores ${ }^{122}$.

Pleitos y disputas como estos, los mantuvieron con la iglesia de Vitoria ${ }^{123}$, con la de Alfaro ${ }^{124}$, con la colegial de Soria ${ }^{125}$ o con la iglesia de Calahorra ${ }^{126}$. Cada litigio retrasaba los cobros y ahondaba las dificultades del tribunal, de modo que casi siempre, terminaban por llegar a ajustes amistosos que no dificultasen en adelante los ingresos, en los que el fisco inquisitorial salía perdiendo parte de lo debido, pero con la seguridad de poder efectuar un ingreso inmediato.

Ciertamente la documentación refleja la inversión del tribunal en censos en diversos lugares del distrito (EI Ciego, Dávalos, Autol, Logroño..), pero no asî una recuperación en sus arcas.

El receptor era quien se encargaba de cobrar los censos redimidos y de remitir sus importes al Consejo ${ }^{127}$, siempre interesado en conocer las cantidades de maravedies que paraban en las arcas procedentes de estos censos y por saber si en el distrito había efectos y fincas seguras en las que imponer alguno ${ }^{128}$.

Pero, los cobros no fueron asuntos siempre sencillos y cuando en 1705 , recién llegado el nuevo Inquisidor General Vidal Marín, se le pregunta al tribunal por el dinero que había en las arcas procedentes de capitales de censos redimidos, se contesta que no había ni un solo maravedí ${ }^{129}$.

El tribunal deja 1705 presentando una situación desoladora. Los censos habian bajado un 3\%, lo que suponía por un lado, unos 5.000 reales menos de ingresos y además que los arrendamientos de los canonicatos bajarían en los nuevos arriendos, padeciéndose mucho en las ciudades de las iglesias donde gozaban de ellos por el hielo, la piedra e inclemencias que por entonces esta-

\footnotetext{
122 A.H.N. Inq. leg. 2221, T/1.G. 2/1/1700.

t23 A.H.N. Inq. lib. 825 , fol, 483 r, Madrid 27/5/1702.

124 A.H.N. lnq. leg. $2221,27 / 4 / 1703$ y $10 / 5 / 1703$.

${ }^{125}$ A.H.N. Inq. leg. 2221, T/C 19/7/1703; lib. 825, fol. 491, Madrid 3/9/1703, leg. 2222, exp. 3 T/C 27/2/1706.

126 A.H.N. lnq. leg. 2222, exp. 2 Calahorra 9/11/1705, T/C 24/1 1/1705.

127 A.H.N. Inq. leg. 2220, exp. 248, T/C 14/10/1690; exp. 247, T/C 7/11/1690; exp. 255c, T/C 8/7/1695; exp. 256, T/C 16/9/1695; lib.825, fol. 401, Madrid 30/10/1696, fol. 427 Madrid 8/8/1698, fol. 437r Madrid 8/4/1699, fol. 468v-469r Madrid 6/10/1700; leg. 2221, T/C 11/9/1700.

12K A.H.N. Inq. lib. 825, fol, 409v, Madrid 17/4/1697, fol. 410r Madrid 19/4/1697.

129 A.H.N. lnq. leg. 2222, exp. 3, T/C 24/10/1705. 
ban sufriendo ${ }^{130}$. Imaginamos que en los años siguientes, envueltos en una guerra «civil» como fue la de Sucesión, la situación y su penuria aumentarían en extremo.

Además, los secuestros fueron en esta etapa, prácticamente inexistentes.

Entre 1690 y 1705 sólo encontramos noticias del efectuado a los encausados por molinosismo en Tudela en los años 88-89 y del de algunas alhajuelas y poco dinero que llevaban una mujer y sus hijos acusados de judaizantes, al ser detenidos en su camino hacia Francia ${ }^{131}$.

Así pues, las dificultades para cubrir los gastos del tribunal debieron ser inmensas y esto se percibe especialmente en la cuestión del pago de salarios a sus ministros.

El tribunal mismo dice en 1690 que debido a "la injuria de los tiempos y quiebra en los arrendamientos que son muy cortos, no basta ni para pagar salarios ordinarios y demás gastos" 132.

Los salarios, en teoría, se pagaban en tercios adelantados, pero en Logroño en estos años, lo habitual era todo lo contrario. Retrasos de tres o cuatro tercios eran, más que una excepción, norma común.

Las ayudas de costa aun eran más difíciles de cobrar, al menos a corto plazo.

SUELDOS Y AYUDAS DE COSTA, LOGROÑO 1690-1705

\begin{tabular}{lcc} 
& sueldo & ayuda de costa \\
\hline inquisidores y fiscales & 250.000 maravedies & 50.000 \\
\hline receptor & 92.000 & 20.000 \\
\hline alguacil mayor y secretarios secreto & 80.000 & 20.000 \\
\hline alcaide cárceles secretas & 60.000 & 40.000 \\
\hline secretario secuestros & 55.000 & 20.000 \\
\hline nuncio y portero & 40.000 & 10.000 \\
\hline contador & 20.000 & - \\
\hline notario del juzgado & 10.000 & - \\
\hline alcaide penitencia y proveedor & 9.000 & - \\
\hline procurador del fisco & 8.000 & - \\
\hline abogado del fisco & 8.000 & - \\
\hline depositario pretendientes & $3 \%$ vellon $2 \%$ plata depositada \\
\hline
\end{tabular}

No todos los ministros que servían en Logroño recibían su sueldo de las arcas riojanas, así el inquisidor Ibáñez cobraba el salario de su plaza en la inquisición de Mallorca ${ }^{133}$ y el secretario de secreto Pedro de Mendoza del

\footnotetext{
130 A.H.N. Inq. leg. 2222, exp. 2, T/C 17/10/1705.

131 A.H.N. Inq. leg. 2220, exp. 254, T/C 10/6/1695; exp. 282, T/C 20/9/1698; leg. 2221, T/C 22/10/1701.

${ }_{132}$ A.H.N. Inq. lib. 821 , fol. 9-12, T/C y T/lG $4 / 2 / 1690$.

t33 A.H.N. lnq. leg. 2221, T/C 19/10/1702.
} 
tribunal de Cuenca ${ }^{134}$, aunque tan impuntualmente como el resto de sus colegas.

Las quejas del tribunal ante la falta de pago de los ministros y por la estrechez que les hacía padecer ${ }^{135}$, junto a los memoriales de los propios oficiales, exponiendo la situación apurada que vivían, aparecen continuamente en la correspondencia del tribunal.

En 1700 los secretarios del secreto decían que hacía cuatro años que no cobraban ayudas de costa y que los tercios, en lugar de adelantados, siempre los cobran retrasados, con lo que padecían estrechez de medios notoria para el sustento de sus casas y familias, con la imposibilidad de mantenerse con la decencia que correspondía a su ministerio y calidad, añadiendo que sus emolumentos eran tan limitados que no llegaban a un tercio de lo que se estilaba en otros tribunales ${ }^{136}$. Aunque no dudamos de la veracidad de estas noticias, estamos seguros que en más de una ocasión, éstas son exageradas pues como hemos señalado en los capítulos anteriores, la economía de los ministros del tribunal era en general, más bien desahogada.

Los primeros años del siglo XVIII, estuvieron protagonizados por los proyectos de reajuste del funcionamiento de la hacienda de la Inquisición, buscando con ello solventar la caótica situación que padecía.

En esta línea, el Consejo e Inquisidor General, Mendoza y Sandoval, disponen en 1702 que el tribunal no pagase salario a los ministros que no sirvieran sus oficios en el actual ejercicio hasta lo hubieran hecho con los que si estaban sirviendo ${ }^{137}$. A finales de ese mismo año, los encontramos pidiendo al tribunal tres relaciones, en las que debían especificar el número ministros ejerciendo, jubilados y sin actual ejercicio, junto al estado de la hacienda que gozaba el tribunal y los gastos que tenían ${ }^{138}$.

Con el decreto de 2 de mayo de 1703, el Consejo y la Corona dispusieron, entre otras importantes medidas, a qué ministros debían pagarse salario y ayuda de costa.

En septiembre de 1704, recuerdan al tribunal estas disposiciones y piden cuenta de su cumplimiento, ante un nuevo decreto real emitido en agosto, advirtiendo, como consecuencia de las tensas relaciones Corona-Inquisidor General Mendoza y Sandoval, que no cumpliesen órdenes del Inquisidor General sin que vinieran señaladas por el Consejo ${ }^{139}$. A pesar de todo, el tri-

\footnotetext{
134 A.H.N. Inq. leg. 2221, T/C 17/2/1703; leg. 2222 exp. 1 Cuenca 10/6/1704; ib. 825, fol. 496v Madrid 21/6/1704, fol. 499r Madrid 25/6/1705.

135 A.H.N. Inq. leg. 2220, exp. 282, T/C 20/9/1698.

136 A.H.N. Inq. leg. 2221, Logroño 1/4/1700, esta queja presentada en un memorial aj Consejo venía provocada por la dispensa que el Inquisidor General había hecho a cuatro pretendientes para que los ministros del secreto no salieran a hacer las pruebas privándolos del estipendio que para ellos suponian la elaboración de las informaciones.

137 A.H.N. Inq. leg. 2221, Madrid 16/5/1702, T/C 27/5/1702.

138 A.H.N. [nq. leg. 2221, T/C $2 / 1 / 1703$.

139 A.H.N. Inq. leg. 2222 , exp. I $13 / 9 / 1704$.

Hispanita, LYII/2, núm. 196 (1997) 731-773
} 
bunal avisa del asunto a Mendoza y Sandoval, sin contravenir las órdenes del Consejo, y le pide disponga cuanto antes lo que deben ejecutar ${ }^{140}$.

Después, con la llegada de Vidal Marín, de nuevo son requeridas todo tipo de informaciones respecto al personal, gastos e ingresos del tribunal ${ }^{141}$ con objeto de replantear el funcionamiento de estos aspectos del Santo Oficio, aunque las incidencias de estas medidas se escapan, al marco temporal tomado para este trabajo.

Pero no sólo eran los sueldos de la mayoría de los ministros que ejercían en esos momentos los que el tribunal debía afrontar como gasto ordinario.

En determinados casos, cuando un oficial desempeñaba eventualmente otro cargo recibía una cierta cantidad de dinero, normalmente a modo de ayuda de costa, por sus servicios.

A pesar de estar dispuesto que un oficial no recibiría más sueldo que el del cargo que detentase en propiedad, Martín Antonio de Badarán en 1696, secretario de secuestros por entonces y receptor en interin, reclamó y logró no solo ayuda de costa, sino el sueldo correspondiente a la receptoría que detentó tres años, alegando que lo mismo se había hecho anteriormente con otros oficiales con cargos en ínterin ${ }^{142}$. Por su lado, Tomás Fernández de Esquide reclamó el pago del salario y ayuda de costa por el tiempo que sirvió la alcaldía de las cárceles secretas sin título mientras se le hacían sus pruebas, petición que logra, aun con el parecer negativo del tribunal ${ }^{143}$.

También ocurría que, en determinadas circunstancias, se asignaba ayuda de costa a la viuda e hijos de algún ministro en compensación por los servicios prestados y en atención a la pobreza que padecían ${ }^{144}$, todo lo cual incrementaba el grueso de las salidas del fisco del tribunal.

Los inconvenientes que la falta de pago originaba en el funcionamiento del tribunal no eran pocos.

Por un lado el hastío, desinterés y desidia de los ministros. El mismo tribunal decía en 1690 que como «..no se paguen los salarios que deben, el próximo año no hallarán quien sirva la receptoria, que estaba en interin, en vista de la quiebra de las rentas y malas pagas... 145.

En medio de este déficit hacendístico las actuaciones fraudulentas, los abusos y desvíos de dinero por parte de los propios oficiales del tribunal no eran infrecuentes.

\footnotetext{
140 A.H.N. Inq. leg. 2222, exp. 1, T/I.G. 13/9/1704.

141 A.H.N. Inq. leg. 2222, exp. 2, 27/6/1705, C/T 10/10/1705, 26/10/1705; lib. 825, fol. 499v, Madrid 6/7/1705.

142 A.H.N. Inq. lib. 825 , fol. 390v C/T 16/2/1696, fol. $427 \mathrm{v}$ C/T 12/8/1698, fol. $429 \mathrm{v}$ C/T 7/1 1/1698; leg. 2220, exp. 277a, b T/C $21 / 77 / 1698$, exp. 277d 2/12/1698, exp. 269 C/T 9/8/1698, exp. $2902 / 12 / 1698$.

143 A.H.N. Inq. leg. 2221, T/C 13/1/1703; lib.825, fol. 488r Madrid 15/12/1702, Madrid $16 / 2 / 1703$.

144 A.H.N. Inq. lib. 825, fol. 404v-405r Madrid 24/1/1697; leg.2222, exp. 2, Madrid 10/9/1699.

145 A.H.N. Inq. leg. 2220, exp. 245, T/C 3/8/169p.
}

Hispania. LVII/2, núm. 196 (1997) 731-773 
Los receptores anualmente o al finalizar su tenencia, debfan dejar liquidadas las cuentas. Realmente las cobranzas no eran sencillas y a la hora de redimir los censos de varas cobrados siempre el saldo era en su contra, asi que lo más frecuente era que se excusasen de saldar las cuentas, alegando falta de efectivo para pagar el alcance y los salarios pendientes.

Tal fue el caso de Tomás de Padura, teniente receptor de 1685 a 1690, quien al finalizar su tenencia se excusó de pagar el alcance, alegando los motivos mencionados. Sin embargo, el tribunal descubriría a través del libro de "caja y razón" que podía haber pagado, pero que en su lugar, había tomado el efectivo para sí, por lo que consideraba necesaria una acción judicial contra él, para que cumpliera con sus pagos ${ }^{146}$. Al final acabó satisfaciendo su deuda, aunque muy lentamente, sin que se tomasen más medidas en su contra ${ }^{147}$. Otro oficial que tomó para si, dinero del fisco del tribunal, fue Martín Antonio de Badarán, quien, alegando la suma necesidad de su familia ante la mala situación que vivía el país en esos años, tom 6 el alcance de un secuestro. El tribunal negó tal necesidad, probando era hombre de mucha hacienda ${ }^{148}$ pero, aun así, no queda claro si restituyó o no la cantidad sustraida, aunque lo cierto es que continuó ejerciendo sus labores en el tribunal.

Otra fuente de abusos fueron las dietas cobradas por los ministros en la elaboración de las informaciones a los pretendientes.

En 1698 los hermanos Bustamante aparecen ante el Consejo con una protesta por lo que se les llevó por sus informaciones, por parte de los ministros del tribunal asignados para hacerlas.

El abuso se comprobó y el Consejo, mostrando de nuevo una actitud comprensiva ante estas irregularidades, advirtió al tribunal que en adelante mirasen con justificacion las cuentas de las informaciones para que los pretendientes no padecieran agravio, ni se quejasen y al secretario del secreto y comisario que habłan cometido la infracción se les obligó a restituir lo cobrado de más ${ }^{149}$. Algo similar ocurrió con las informaciones de los hermanos Urtecho encargadas a los hermanos Vélez de Vergara, secretario del secreto y comisario de Casa la Reina. Sin embargo, estos además de ser obligados a restituir lo cobrado de más, fueron suspendidos por un año, de sus salidas a realizar informaciones, aunque al final, esto último no llegó a cumplirse, al dispensarles el Inquisidor General ${ }^{150}$.

El tribunal debía enviar al Contador General los depósitos efectuados en la depositaría de pretendientes, incluyendo los derechos de fábrica de Sevilla y los de la media annata, así como los alcances tomados por el receptor cada año. En determinadas ocasiones el Consejo accedía a retrasar el envío de algunas de estas partidas, atendiendo a las acuciantes necesidades del tribunal, aunque siempre a condición de ser restituidas más tarde ${ }^{151}$.

146 A.H.N. Inq. leg. 2220, exp. 246 T/C 12/9/1690, exp. 248 T/C 14/10/1690.

147 A.H.N. Inq. leg. 2220 , exp. $247 \mathrm{~T} / \mathrm{C} 7 / 11 / 1690$.

148 A.H.N. Inq. leg. 2220, exp. 289 6/l 1/1698; exp. 277c T/C 29/1 1/1698.

149 A.H.N. Inq. leg. 2220 , exp. $259 \mathrm{~b}, \mathrm{c}, \mathrm{d}$ T/C $21 / \mathrm{l} / 1698$.

150 A.H.N. Inq. leg. 2221, exp. $49 \mathrm{~b}, \mathrm{~T} / \mathrm{C} 21 / 4 / 1700$.

151 A.H.N. Inq. lib. 825, fol. 394r C/T 1476/1696.

Hispania, LVIL/2, núm. 196 (1997) 73 J-773 
Desde Logroño se debía dar cuenta al Consejo de todas las gestiones hechas en materia hacendística. En teoría el tribunal debía enviar al fiscal del Consejo noticias sobre las juntas de hacienda celebradas y los ingresos, gastos..etc. que se produjeran, sin embargo no parece que ni las juntas, ni los informes fueran todo lo regulares que se esperaba, con lo que encontramos en más de una ocasión llamadas de atención desde Madrid, bien para que actuasen conforme a lo previsto, indicando incluso cómo disponer los términos de los informes ${ }^{152}$, o bien, pidiendo explicaciones de la gestión realizada, o de las diferencias detectadas entre las cuentas del tribunal y las del Contador General ${ }^{153}$.

Entre los gastos extraordinarios del tribunal estaban los contraídos en celebraciones funerarias, túmulo y honras en memoria de los miembros de la familia real ${ }^{154}$

La Corona también utilizó a la Inquisición como fuente de ingresos cuando lo necesitó y en los primeros años del xvmital circunstancia se dio con relativa intensidad.

En 1702 por real decreto se ordenó al tribunal remitir al Consejo una letra de tres doblones por cada inquisidor y fiscal y de un doblón por cada ministro que gozase salario ${ }^{155}$. Poco después, en 1704, por real decreto de 10 de noviembre, se ordenó a todos los tribunales que pagasen por un año lo que importara el 5\% de los salarios de todos los ministros. El Consejo debió hacer recuerdo de esta orden en abril del año siguiente, ante su incumplimiento y el tribunal de Logroño respondió que, al menos hasta septiembre, no podría remitir tal cantidad por hallarse entonces sin efecto alguno el fisco y tener que esperar hasta el cobro de los plazos de las rentas de canonicatos ${ }^{156}$.

En 1705, ante un nuevo decreto real publicado en Logroño, por el que se pedía un donativo para la Corona, cargando sobre las tierras, casas y ganados de cada vecino, el tribunal preguntó al Consejo si estaban o no comprendidos en él los ministros titulares. La respuesta fue que se aplicase lo resuelto en Córdoba, sin que sepamos, de momento, cual fue tal resolución ${ }^{157 .}$

En definitiva, pocos ingresos en un ambiente de crisis generalizada y un volumen de gastos fuerte, ahondado por la corrupción de los oficiales del tribunal provocaron que la inquisición logroñesa viviera esta etapa en precario, aunque todo esto no quiere decir que sus ministros, en su mayoría poseedores de otras fuentes de ingresos ajenas al tribunal, padecieran la misma suerte.

152 A.H.N. Inq. lib. 825, fol. $402 \mathrm{v}-403 \mathrm{r}$ C/T 12/2/1696; fol. $409 \mathrm{v}$ T/C $17 / 4 / 1697$, fol. $410 \mathrm{r}$ T/C 19/4/1697; leg. 2221, T/C 22/10/1701.

153 A.H.N. Inq. lib. 825, fol. 393v C/T 26/5/1696.

154 Caso de la Reina madre, A.H.N. Inq. lib. 825 fol. $395 \mathrm{v}-396 \mathrm{r}$, C/T $7 / 7 / 1696$, fol. $397 \mathrm{v}$ C/T $16 / 8 / 1696$

155 A.H.N. Inq. leg. $2221, \mathrm{~T} / \mathrm{C} 18 / 4 / 1702$.

156 A.H.N. Inq. leg. 2222 exp. 2 Madrid 20/471705, T/C 1975/1705; lib. 825, fol. 498v Madrid $26 / 5 / 1705$.

157 A.H.N. Inq. leg. 2222, exp. 2 T/C 10/3/1705,

Hispanio, LVII/2, núm. 196 (1997) 731-773 